Portland State University

PDXScholar

\title{
Maintaining Safe, Efficient and Sustainable Intermodal Transport Through the Port of Portland
}

\author{
David A. Jay \\ Portland State University, djay@pdx.edu \\ Jiayi Pan \\ Portland State University
}

Follow this and additional works at: https://pdxscholar.library.pdx.edu/cengin_fac

Part of the Civil and Environmental Engineering Commons, and the Transportation Commons Let us know how access to this document benefits you.

\section{Citation Details}

Jay, David A. and Jiayi Pan. Maintaining Safe, Efficient and Sustainable Intermodal Transport Through the Port of Portland. OTREC-RR-11-17. Portland, OR: Transportation Research and Education Center (TREC), 2011. http://dx.doi.org/10.15760/trec.111

This Report is brought to you for free and open access. It has been accepted for inclusion in Civil and Environmental Engineering Faculty Publications and Presentations by an authorized administrator of PDXScholar. Please contact us if we can make this document more accessible: pdxscholar@pdx.edu. 


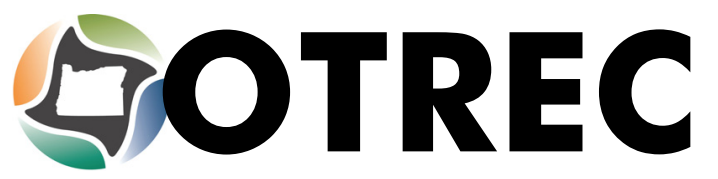

FINAL REPORT

\section{Maintaining Safe, Efficient and Sustainable Intermodal Transport through the Port of Portland}

OTREC-RR-11-17

October 2011 



\title{
Maintaining Safe, Efficient and Sustainable Intermodal Transport through the Port of Portland
}

\author{
Final Report \\ OTREC-RR-11-17 \\ by \\ David A. Jay \\ Jiayi Pan
}

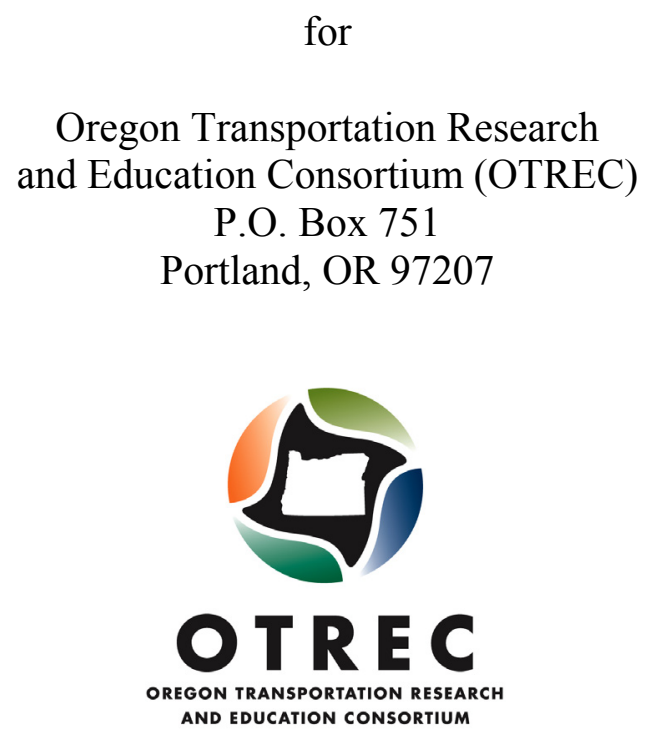

October 2011 



\begin{tabular}{|c|c|c|c|c|c|}
\hline $\begin{array}{l}\text { 1. Report No. } \\
\text { OTREC-RR-11-17 }\end{array}$ & \multicolumn{3}{|c|}{ 2. Government Accession No. } & \multicolumn{2}{|c|}{ 3. Recipient's Catalog No. } \\
\hline \multirow{2}{*}{\multicolumn{4}{|c|}{$\begin{array}{l}\text { 4. Title and Subtitle } \\
\text { Maintaining Safe, Efficient and Sustainable Intermodal Transport } \\
\text { through the Port of Portland }\end{array}$}} & \multirow{2}{*}{\multicolumn{2}{|c|}{$\begin{array}{l}\text { 5. Report Date } \\
\text { October } 2011\end{array}$}} \\
\hline & & & & & \\
\hline \multicolumn{4}{|l|}{$\begin{array}{l}\text { 7. Author(s) } \\
\text { Dav id A. Jay } \\
\text { Jiayi Pan }\end{array}$} & \multicolumn{2}{|c|}{ 8. Performing Organization Report No. } \\
\hline \multirow{2}{*}{\multicolumn{4}{|c|}{$\begin{array}{l}\text { 9. Performing Organization Name and Address } \\
\text { Department of Civil and Environmental Engineering } \\
\text { Portland State University } \\
\text { PO Box } 751 \\
\text { Portland, OR } 97207 \\
\text { David A. Jay }\end{array}$}} & \multicolumn{2}{|c|}{ 10. Work Unit No. (TRAIS) } \\
\hline & & & & \multicolumn{2}{|c|}{ 11. Contract or Grant No. } \\
\hline \multirow{2}{*}{$\begin{array}{l}\text { 12. Sponsoring Agency Name and Addres } \\
\text { Oregon Department of Transportation } \\
\text { Research Unit } \\
\text { 200 Hawthorne Ave. SE, Suite B-240 } \\
\text { Salem, Oregon 97301-5192 } \\
\end{array}$} & \multirow{2}{*}{\multicolumn{3}{|c|}{$\begin{array}{l}\text { Oregon Transportation Research } \\
\text { and Education Consortium (OTREC) } \\
\text { P.O. Box } 751 \\
\text { Portland, Oregon } 97207\end{array}$}} & \multicolumn{2}{|c|}{$\begin{array}{l}\text { 13. Type of Report and Period Covered } \\
\text { Final Report } \\
\text { October } 2008 \text { to December } 2010\end{array}$} \\
\hline & & & & \multicolumn{2}{|c|}{ 14. Sponsoring Agency Code } \\
\hline \multicolumn{6}{|l|}{ 15. Supplementary Notes } \\
\hline \multicolumn{6}{|c|}{ 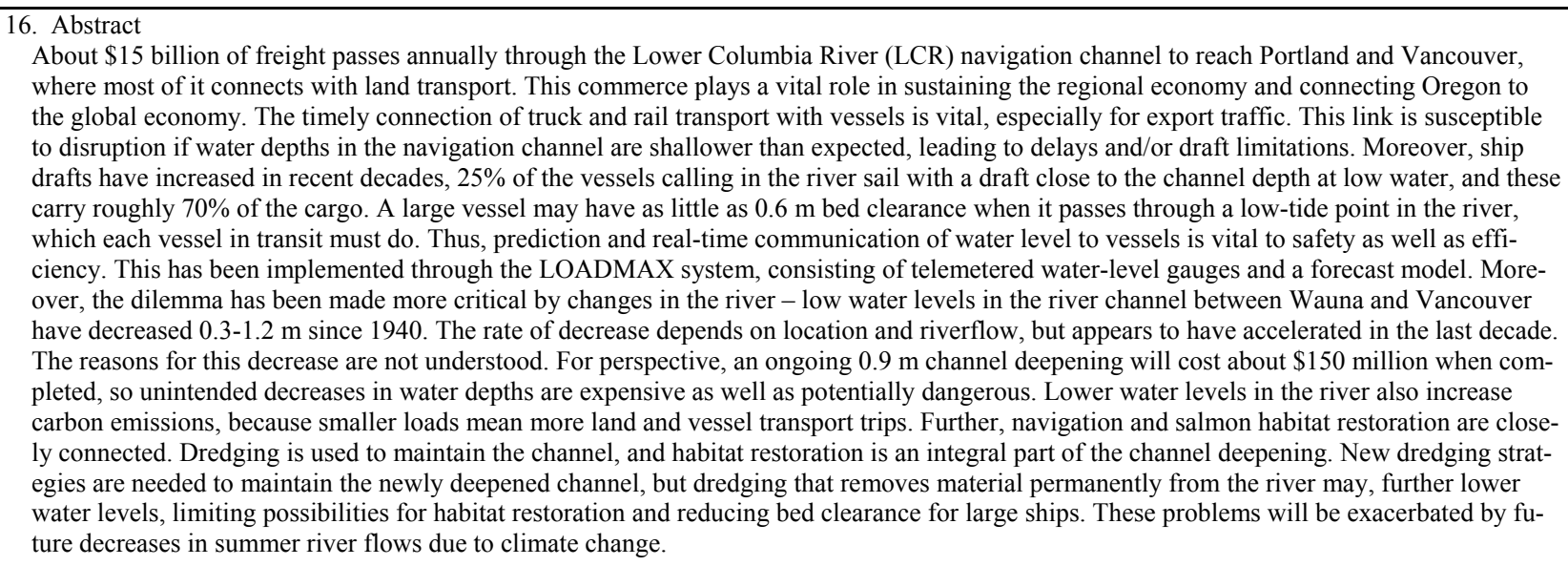 } \\
\hline \multicolumn{2}{|c|}{$\begin{array}{l}\text { 17. Key Words } \\
\text { Lower Columbia River, Water Levels, Portland-Vancouver Harbor }\end{array}$} & \multicolumn{4}{|c|}{$\begin{array}{l}\text { 18. Distribution Statement } \\
\text { Copies available online at: }\end{array}$} \\
\hline $\begin{array}{l}\text { 19. Security Classification (of this report) } \\
\text { Unclassified }\end{array}$ & $\begin{array}{l}\text { 20. Security Classifi } \\
\text { Unclassified }\end{array}$ & page) & & of Pages & 22. Price \\
\hline
\end{tabular}





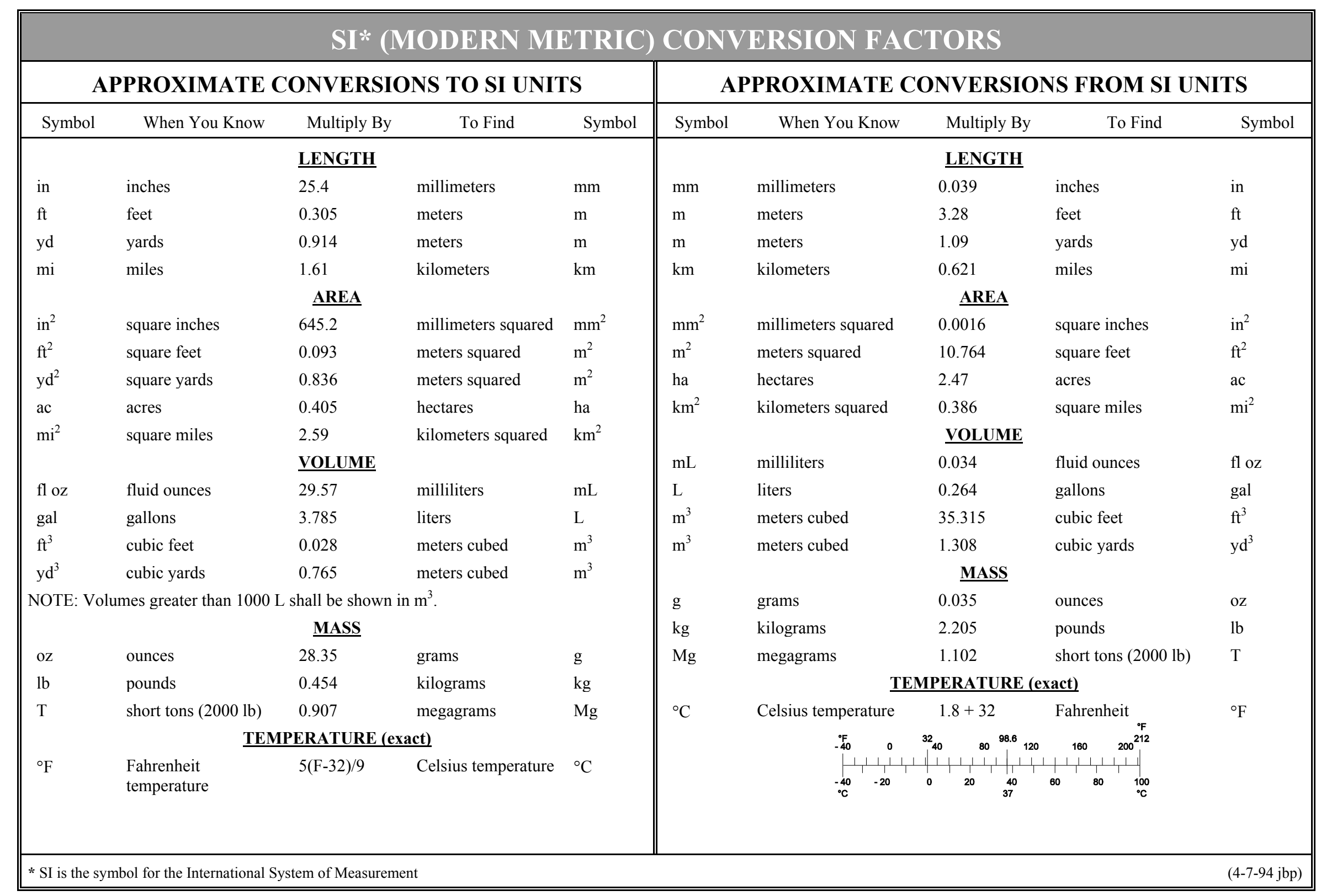





\section{ACKNOWLEDGEMENTS}

This project was funded by the Oregon Transportation Research and Education Consortium (OTREC), the Bonneville Power Administration, and the U.S. Army Corps of Engineers, Portland District. We thank Port of Portland personnel Sebastian Degens and Eric Burnette for their assistance in the performance of this work.

\section{DISCLAIMER}

The contents of this report reflect the views of the authors, who are solely responsible for the facts and the accuracy of the material and information presented herein. This document is disseminated under the sponsorship of the U.S. Department of Transportation University Transportation Centers Program and Portland State University in the interest of information exchange. The U.S. Government and Portland State University assume no liability for the contents or use thereof. The contents do not necessarily reflect the official views of the U.S. Government or Portland State University. This report does not constitute a standard, specification, or regulation. 


\section{TABLE OF CONTENTS}

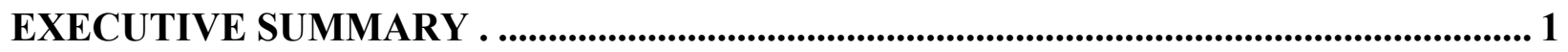

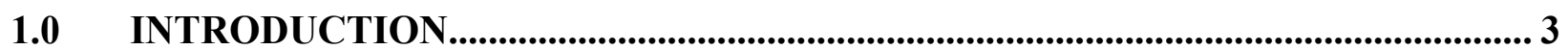

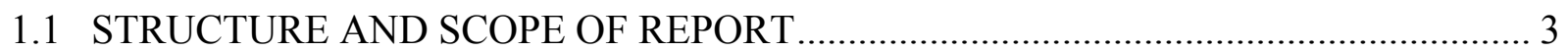

1.2 THE PROBLEM: FALLING WATER LEVELS........................................................ 3

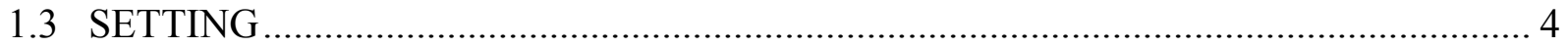

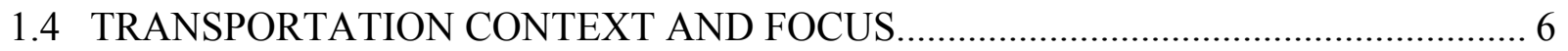

2.0 PREVIOUS ANALYSES OF EVOLVING TIDES ...................................................... 9

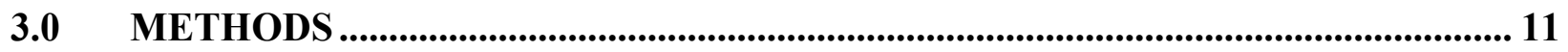

3.1 DATA SOURCES ………………………………….................................... 11

3.2 RIVER RIDES AND DATUM LEVELS -- THEORY .............................................. 12

3.3 RIVER TIDES AND DATUM LEVELS -- PRACTICAL REGRES-SION MODELS.. 14

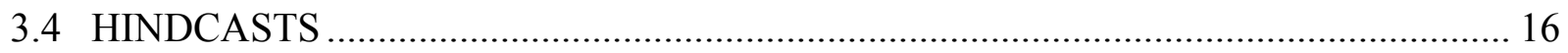

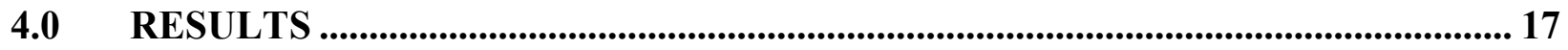

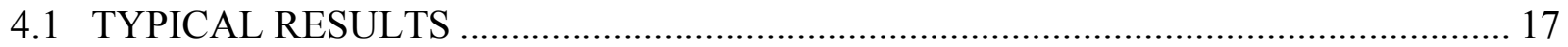

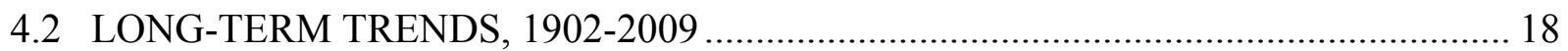

4.3 CHANGES IN LLW AND HHW DATUM LEVELS AS A FUNCTION OF FLOW

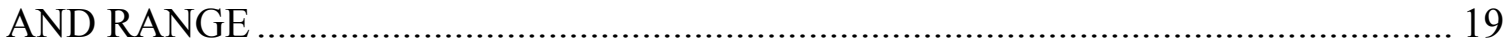

4.4 CHANGES IN THE INCIDENCE OF VERY LOW WATER LEVELS ......................... 21

5.0 DISCUSSION .................................................................................................................... 23

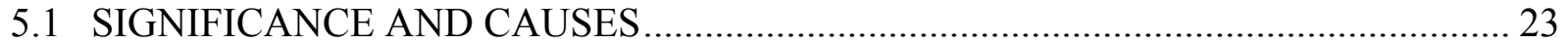

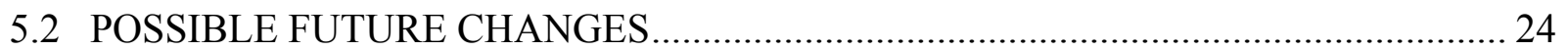

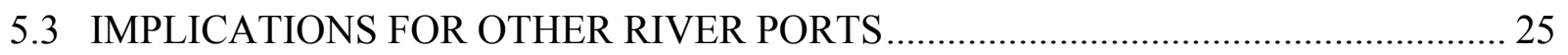

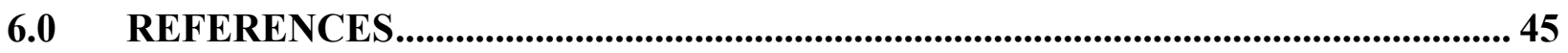

APPENDICES

APPENDIX A: Toward a Sand Budget for the Lower Columbia River 27

\section{LIST OF FIGURES}

Figure 1.1: Study Context - changes in the incidence of low-water levels, 1902-2009................. 4

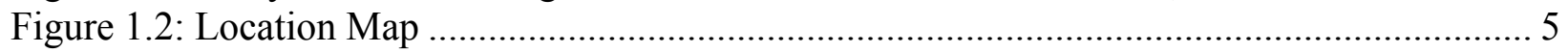

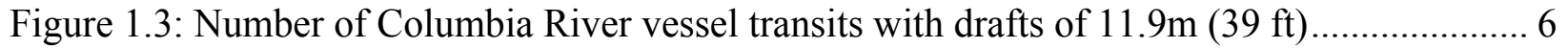

Figure 4.1: Vancouver LLW model results for 1972-1980 …………..................................... 18

Figure 4.2: Modeled values of Vancouver HHW, MWL and LLW for all time periods ........... 19 Figure 4.3: Modeled values of Vancouver HHW and LLW for selected tidal ranges and flows 20 Figure 4.4: Hindcast (1925-2009) and observed (1973-2009) number of days per year on which the LLW at Vancouver was less than the specified value 


\section{EXECUTIVE SUMMARY}

A 170-kilometer tidal channel connects the Lower Columbia River ports of Portland and Vancouver to the Pacific Ocean. About $\$ 15$ billion of freight passes annually through the Lower Columbia River navigation channel to reach Portland and Vancouver, where most of it connects with land transport. This commerce plays a vital role in sustaining the regional economy and connecting Oregon to the global economy. The timely connection of truck and rail transport with vessels is vital, especially for export traffic. This link is susceptible to disruption if water depths in the navigation channel are shallower than expected, leading to delays and/or draft limitations. Moreover, ship drafts have increased in recent decades (Figure 1.1); 25 percent of the vessels calling in the river sail with a draft close to the channel depth at low water, and these carry roughly 70 percent of the cargo. A large vessel may have as little as 0.6 meters bed clearance when it passes through a low-tide point in the river, which each vessel in transit must do.

An increasing incidence of low water levels during summer and fall sometimes limits the draft of ships using the channel and delays transits. Reduced spring-freshet water levels have also decreased shallow-water habitat for juvenile salmon. Understanding why these changes have occurred requires analyses of long-term water level records and the sediment balance of the system. Water level records from Tongue Point (km-30, 1925-date), and Vancouver (km-175, 1902-date) were used to analyze historic changes. The very sparse character of the available historic data (13 values per day) and the importance of extremal water-level values to navigation both suggested an approach based on mean and extreme water levels, rather than a full analysis of tidal characteristics. Accordingly, three datum levels were chosen for analysis: Mean water levels (MWL), lower low water (LLW) and higher high water (HHW). LLW is the most important datum for navigation. Because of the very strong influence of river flow on water levels, all three of these datum levels must be defined as a function of river flow, using regression models based on tidalfluvial interaction theory. LLW values at Vancouver have dropped 0.3-1.5 meters since 1902, depending on flow. LLW at the lowest river flows has decreased 0.4-0.5 meters since 1940 . Vancouver LLW has dropped more than MWL and HHW, increasing tidal range.

There are several possible causes for the changes in water levels documented here. One likely cause is a decrease in total roughness of the channel due to navigational development and other human alterations. Channelization of the flow into a narrower, deeper channel is another factor likely to alter tides. Doubling depth while halving the momentum-conveying width (a change that approximates the historic changes in many parts of the system) will increase tidal amplitude

by a factor of $2^{1 / 4} \cong 1.19$. Bed degradation, due to reduced sand supply, dredging and sand mining, may also have lowered water levels. Lack of sand supply from the river has also caused degradation of the bed near the ocean entrance and damage to the entrance jetties. This aspect of the problem is also discussed in the Appendix.

Several factors may contribute to future changes in water levels. Climate change scenarios are divided as to whether Columbia Basin precipitation will increase or decrease in the future, but there is broad agreement that temperatures are increasing, yielding (in the absence of altered flow regulation) higher winter and lower summer river flows. Absent flow management to sup- 
port fall flows, we may see, in future dry years, low-flow periods comparable to those that occurred in dry years before construction of the Columbia River reservoir system. This could lead to the occurrence of extended periods of low water levels in the fall, with adverse effects on navigation.

The results of this study informed speculation regarding the possible course of future changes in water levels in the more landward part of the system. In principle, decreases in fluvial water levels are self-limiting because a net slope is required to discharge the substantial river flow of the system. CRD at Vancouver (km-178) is $\sim 1.5$ meters above MLLW at Tongue Point (km-30), yielding is an average slope of $\sim 10^{-5}$. A decrease of this low water slope of 20 percent would cause a further drop of $\sim 0.3$ meters in low-flow water levels in Portland-Vancouver Harbor. While it is unclear whether such decreases will occur, it is difficult, given the history of the system, to exclude this possibility. Whatever changes occur in channel properties, dropping water levels may be ameliorated to some extent by tectonic effects. Still, it is possible that without some change in river flow levels or sediment management, decreases in water levels will continue for some decades.

In summary, tides and water levels in the Lower Columbia River and Portland-Vancouver Harbor are evolving due to a combination of changing ocean tides and local alterations, including both harbor development and river-flow modification. Studies of tidal evolution in other ports indicate that the changes observed in the Columbia are occurring in a number of Northern Europe harbors, though the causes have been little examined and are likely diverse. Thus, the Columbia is by no means an extreme or isolated example. Future impacts of climate change on ports need to be evaluated in the context of the multiple factors affecting the tidal regime of river ports. A warmer climate may influence tides through MSL rise, but also through changes in the coastal tidal regime that influences the adjacent ports. Climate change is also altering the hydrologic regime (flows and sediment transport) of major river systems. Both the direct effects of climate and those of the human response to climate change in the form of manipulation of the flow cycle will be felt downstream, in the tidal regimes of river ports.

The results of this project are being disseminated in the form of two peer-reviewed papers. The first is in press in ASCE Journal of Waterway, Port, Coastal, and Ocean Engineering. The results of this paper are summarized in the text below. The second, now in preparation, is based on a 2009 senior honors project in the Department of Civil and Environmental Engineering of Portland State University. This paper, to be submitted to the ASCE Journal of Waterway, Port, Coastal, and Ocean Engineering, is included in Appendix A. 


\subsection{INTRODUCTION}

\subsection{STRUCTURE AND SCOPE OF REPORT}

Some $\$ 15$ billion of freight passes annually through the Lower Columbia River (LCR) navigation channel to reach Portland and Vancouver, where most of it connects with land transport. This commerce plays a vital role in sustaining the regional economy and connecting Oregon to the global economy. The timely connection of truck and rail transport with vessels is vital, especially for export traffic. This link is susceptible to disruption if water depths in the navigation channel are shallower than expected, leading to delays and/or draft limitations. As documented below, 1902-2009 water level records for Portland-Vancouver Harbor indicate that there has been a steady decrease in water levels since 1940 and, for some river flows, since ca. 1900. The reasons for these recently noticed changes were not understood at the beginning of the study, even though they are of considerable importance for navigation in the system.

This report describes a pioneering effort to document and understand the causes of falling water levels in Portland-Vancouver Harbor. The main body of the text presents the results of a peerreviewed paper now in press in the ASCE Journal of Waterway, Port, Coastal, and Ocean Engineering (Jay et al., 2011). This paper quantifies long-term changes, discusses possible causes, and seeks to bound likely future changes. Appendix A consists of a draft paper based on the senior honors project of Mr. William Templeton, a 2009 graduate of the Department of Civil and Environmental Engineering, Portland State University. Mr. Templeton analyzed the balance of sand input (from upstream) to the Lower Columbia River and the removal of material from the system by dredging, sand mining and land creation. After further revision, this draft paper will be submitted to the ASCE Journal of Waterway, Port, Coastal, and Ocean Engineering. It has not at this time been peer reviewed.

\subsection{THE PROBLEM: FALLING WATER LEVELS}

The Lower Columbia River serves many human and ecosystem functions, including navigation, salmon habitat and transit, and power generation. This paper analyzes historic changes in tidal datum levels (lower low water (LLW), higher high water (HHW), and mean water level (MWL)) in the Columbia; considers their possible causes; and relates processes in the Columbia to those in other heavily modified river estuaries. The impetus for this study was a recent increase in the number of days with very low water levels in the landward part of the tidal river (Figure 1.1). Low river flows bring low values of LLW from late July to early November, especially on neap tides. These may delay the sailing of deep-draft ships and are a potential safety hazard. Reduced values of HHW during the spring freshet period decrease the availability of shallow-water habitat area that is vital to downstream migrant juvenile salmonids, 13 stocks of which are classified as endangered (Bottom et al., 2005). The two issues are connected by a need to maintain adequate water depths for both purposes throughout the year. 


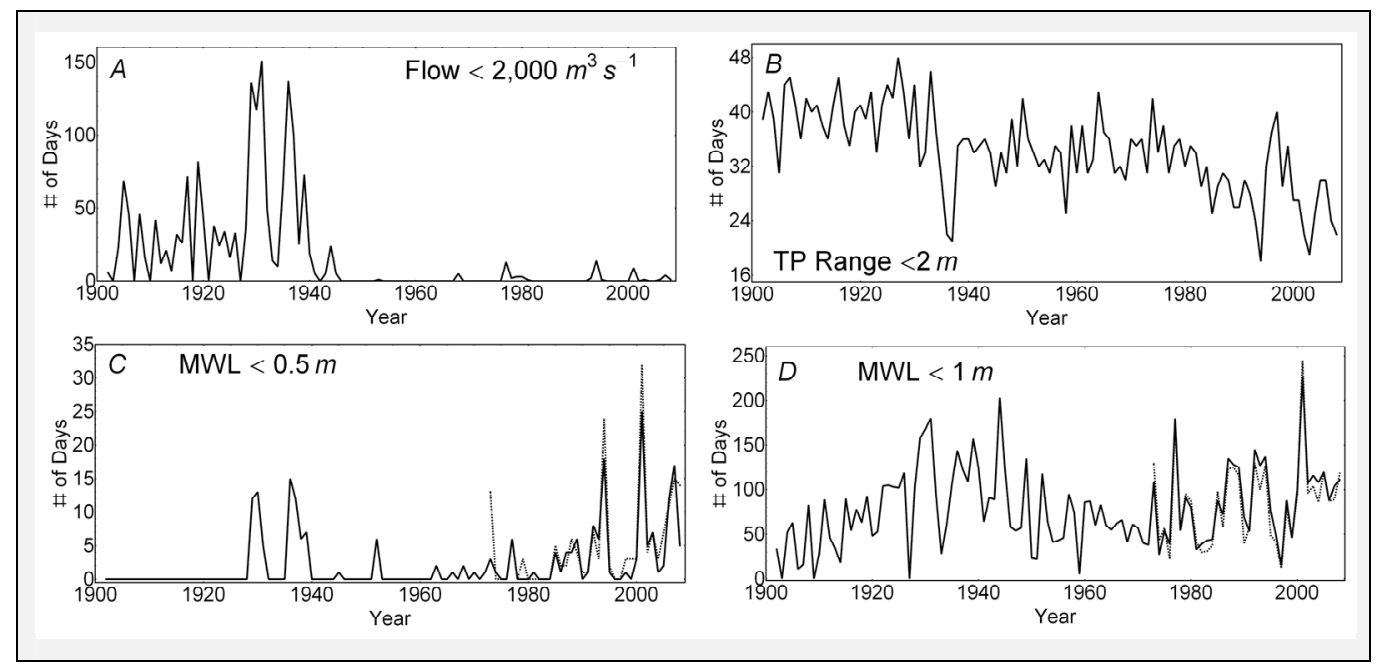

Figure 1.1: Study Context - changes in the incidence of low-water levels, 1902-2009: (a) number of days per year with river flow at The Dalles $\mathrm{Q}_{\mathrm{TD}}<2000 \mathrm{~m}^{3} \mathrm{~s}^{-1}$, ( b) number of days with Tongue Point greater diurnal tidal range (GDTR) $<2$ m, (c) number of hindcast (1902-2009, solid) and observed (1973-2009, dotted) days per year with $\mathrm{MWL}<0.5 \mathrm{~m}$ at Vancouver, and (d) same but with $\mathrm{MWL}<1 \mathrm{~m}$ at Vancouver.

The increase in low-water days shown in Figure 1.1 has occurred despite a decrease in the occurrence of two factors that reduce bed friction, river slope and water levels: very low river flows, and small ocean tidal ranges. The decrease in low-flow days is a result of reservoir system construction and the need for year-around hydropower generation. It has occurred along with $\sim 17$ percent and 45 percent decreases, respectively, in mean and spring-season flows since 1900 (Naik and Jay, 2005). An increase in tidal amplitudes throughout the Northeast Pacific (Jay, 2009) has decreased the occurrence of low tidal ranges at the river mouth. We examine and model, therefore, historic changes in the relationship of riverine tidal properties to external boundary forcing by ocean tidal amplitude and river flow. Likely causes and possible future climate impacts are discussed.

\subsection{SETTING}

The Columbia River enters the Pacific Ocean about 30 kilometers seaward of the tide gauge at Tongue Point (Astoria, OR, USA; Figure 1.2), where the mean greater diurnal tidal range (GDTR) is $\sim 2.6$ meters. Northeast Pacific tides are mixed, and the ratio of semidiurnal $\left(\mathrm{D}_{2}\right)$ to diurnal $\left(\mathrm{D}_{1}\right)$ tides is $\sim 1.8$ at Tongue Point. Another major factor affecting navigation and habitat is the strong river flow, which averages $\sim 7,300 \mathrm{~m}^{3} \mathrm{~s}^{-1}$ at the mouth (Bottom et al, 2005).

The Ports of Portland and Vancouver are in the tidal river $\sim 170$ kilometers from the ocean (Figure 1.2); other regional ports are closer to the ocean. Thus, deep-draft ships must navigate a 170kilometer-long navigation channel with adequate under-keel clearance for their entire round-trip transit. Draft is particularly critical for heavily loaded, outbound ships (mostly bulk carriers) because they must pass through a low water during their six- to seven-hour transit to the sea. Inbound ships are usually of lesser draft and can follow the tide. Given this lengthy transit, 
changes in tidal-fluvial interactions may strongly impact navigation. This issue has been previously studied in the Delaware River and some European ports. The problem is, however, also relevant to the Columbia and other North American tidal-river ports (e.g., the Fraser and St. Lawrence Rivers in Canada, and the Fox, Savannah and Sacramento Rivers in the U.S.).

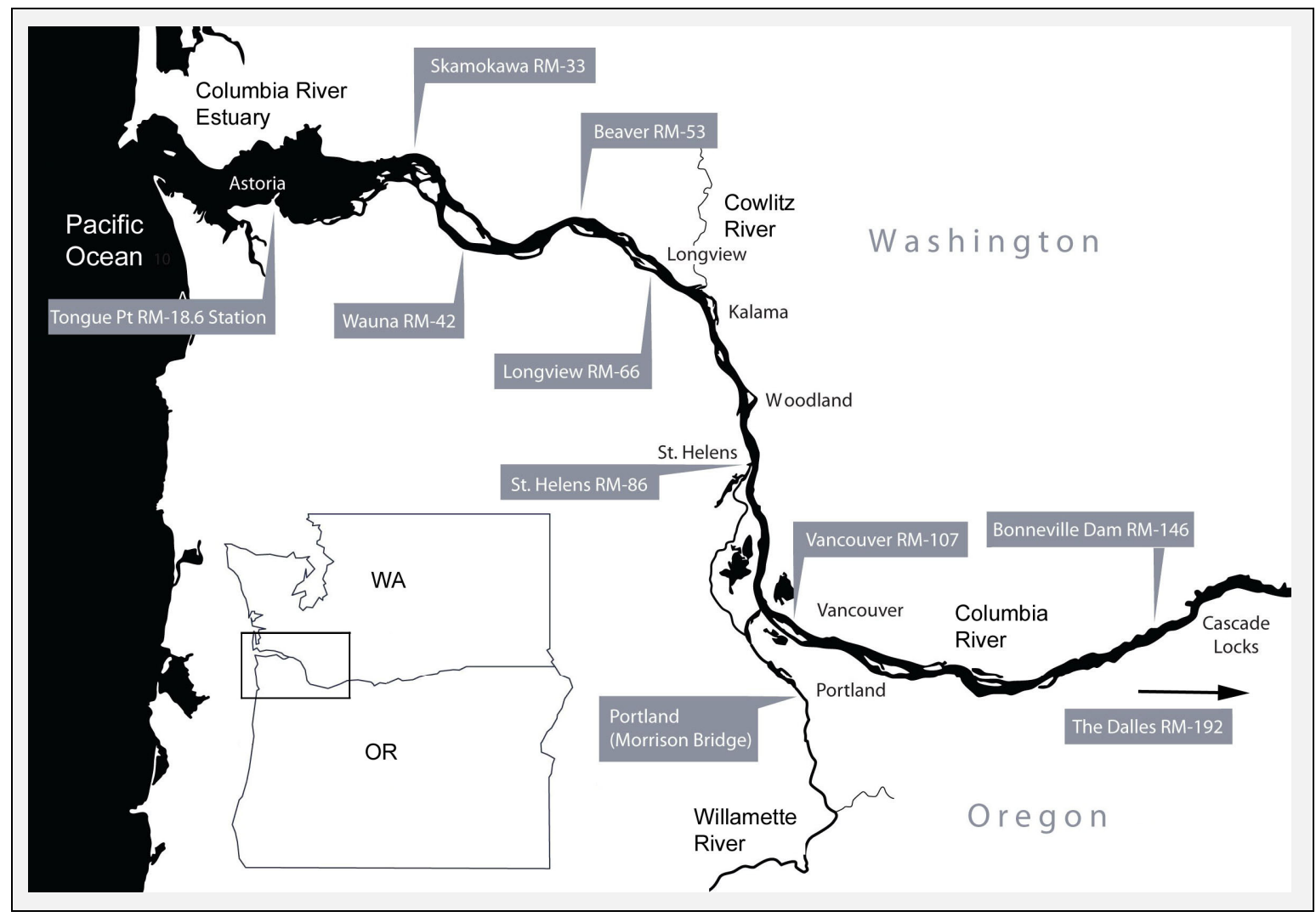

Figure 1.2: Location map for tide stations in the lower Columbia River, with official river-mile designations. NOAA stations include those at the Tongue Pt reference station, Skamokawa, Wauna, Longview, and Vancouver. U.S. Geological Survey gauges at Beaver and Portland are also included in LOADMAX.

The Columbia navigation channel consists of two projects, the entrance (up to five kilometers from the ocean), and the river channel from the entrance to Portland and Vancouver. The natural controlling depth in the river channel was three to six meters, but five to seven meters in the entrance. Channel development began in the 1870s. By 1925, a 9.1-meter channel was authorized, with considerable construction of pile dikes before 1910. A 10.7-meter channel was completed in the 1930s with more pile dike construction, and a 12.2-meter channel was completed by 1975 . A recent deepening of the river channel from 12.2 to 13.1 meters is almost complete. Dredging of the entrance was not feasible until the 1940s and was largely unnecessary due to entrance jetty construction between 1883 and 1939. Because of severe wave conditions, the entrance channel has been deepened to 14.6 meters and then to 16.2 meters (outbound lane only) in the $1980 \mathrm{~s}$. 


\subsection{TRANSPORTATION CONTEXT AND FOCUS}

The issue of water levels in the river channel is important, independent of recent decreases in water level, because ship drafts are increasing. About 25 percent of all vessels calling in the river sail with a draft $>11.6$ meters (38ft; within $1.2 \mathrm{~m}$ of the nominal low-water depth), and these carry a disproportionate share of the cargo. The number of vessels with drafts $\geq 11.9$ meters (39ft) has increased dramatically - from two in 1981 to 290 in 2008 (Figure 1.3). Because at least 0.6-1 meters of under-keel clearance is required for safety, prediction and real-time communication of water levels to pilots is vital for both safety and efficiency. This communication is carried out via LOADMAX, a system of eight telemetered tide gauges between the ocean and PortlandVancouver Harbor (Figure 1.2). Six of these gauges are part of the NOAA (National Oceanic and Atmospheric Administration) PORTS system.

Historic and ongoing changes in water levels also affect shallow-water habitat area. Juvenile salmonids use such habitats during their migration to the ocean, primarily during the high-flow, freshet period, May to July. However, there is some juvenile salmonid use of the system throughout the year (Bottom et al, 2005). Diking of the floodplain and a $\sim 45$ percent reduction in spring freshet flows are the largest causes of reduced availability of spring-season habitat $\mathrm{Ku}-$ kulka and Jay, 2003a,b; henceforth KJ2003). Still, the decreased water levels (for any given flow) discussed below increase the difficulty in restoring shallow-water habitat.

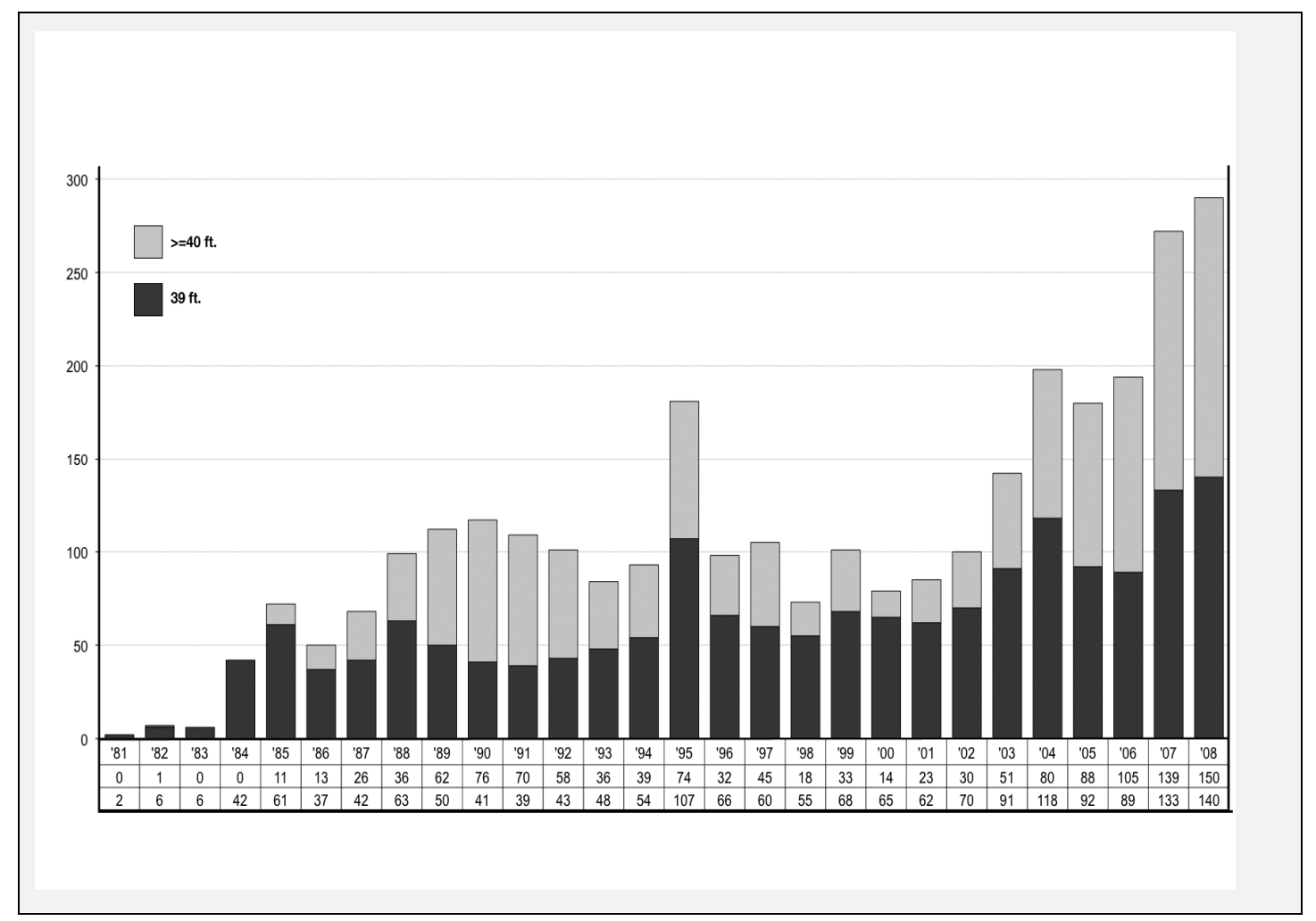

Figure 1.3: Number of Columbia River vessel transits with drafts of 11.9m (39 ft) or more, by year 1981-2008. 
The focus of this analysis is on decadal to centennial changes. For this purpose, river-flow data and records from two long-term water level gauges, Vancouver (1876-2009) at 170 kilometers and Tongue Point (1925-2009) at 30 kilometers, are employed. Tongue Point is at the seaward end of the tidal river, while Vancouver, the most inland major port, is near its landward end. The tide is detectable during low-flow periods to Bonneville Dam (km-245) but diminishes rapidly above Vancouver. Above Vancouver, the tides are hard to detect for high river flows and are often smaller than diel fluctuations caused by fluctuations in power generation ("power peaking"). Thus, Vancouver is the preferred landward end point for the analysis. 


\subsection{PREVIOUS ANALYSES OF EVOLVING TIDES}

Studies of the long-term evolution of tides can be classified by parameters analyzed and by geographic scope, from harbor to ocean-basin scale. It is easiest to diagnose the causes of historic changes when tidal species or constituents are analyzed because tidal theory describes the behavior of these quantities. However, changes in datum levels (e.g., LLW, MWL or HHW) are of greater practical interest, and early tidal records typically provide only extrema. Thus, it is often necessary to focus, as here, on the tidal datum levels that can be derived from such sparse records.

Amin (1983) analyzed changes in tidal constituents in the Thames during two periods: 16831855 and 1929-1979. Tidal ranges increased abruptly after 1835, due primarily to increases in the $\mathrm{D}_{2}$ wave in the modern period; the $\mathrm{D}_{1}$ constituents changed little. Amin concludes that the observed changes are partly due to "secular trends in tidal harmonics and partly due to manmade alterations: embankment, bank raising and deepening of the estuary." Thus, part of the increase in tidal ranges is due to processes in the North Sea and part to human-induced changes. Results presented below for the Columbia suggest a similar duality. This paper documents, however, changes in river stage as well as in tidal range.

DiLorenzo et al. (1993) examined changes in tides in the Delaware River on the U.S. East Coast. Like the lower Columbia up to $\sim 85$ kilometers from the ocean, Delaware Bay is funnel-shaped and has been heavily modified for navigation. It has a dominantly $\mathrm{D}_{2}$ tide that propagates 216 kilometers landward. Dredging doubled navigation channel depths in the system from 6.1 to 12.2 meters between 1910 and 1983. The authors describe the tide in the system in terms of a competition between tidal funneling and friction (cf. Jay, 1991). As a tidal wave propagates in a channel with cross-sectional area decreasing in the landward direction (the funnel), tidal amplitude increases, but the increase is limited by friction. Increased depths (likely with partially compensating changes in width) have been associated with faster tidal wave propagation ( $\sim 50$ percent) and a doubling in tidal range at the landward end. The changes associated with comparable increases in the depth of the Columbia River navigation channel are similar in character but less extreme, probably because of the strong river flow and friction in the system.

Jensen et al. (2003) examined changes in the tides in the Ems, Weser and Elbe river estuaries in Germany. All three systems show increasing tidal ranges that the authors attribute to navigational development. Diking, deepening and other river engineering measures are cited as possible causes, but no dynamical analysis was attempted. In most of these cases, the observed changes are more extreme than in the Columbia, though the apparent causes are similar.

Tides at 13 ports around Great Britain and Ireland show variable changes with no clear pattern (Woodworth et al., 1991). In contrast, seven stations in The Netherlands and several on the German North Sea showed rapid increases in tidal range. For Britain, the authors discount navigational development as a factor, except in the Thames. Instead, they suggest that mean sea level (MSL) rise may have caused movement of the $\mathrm{D}_{2}$ amphidromic point in the relatively shallow 
Celtic Sea. Clearly, multiple factors influence tidal evolution, and not all developed ports show changing tidal properties. Rising sea level is, moreover, not a likely factor for U.S. West Coast ports, because of the relatively deep, narrow shelf along this coast.

Flick et al. (2003) examined changes in tidal datum levels at 90 NOAA stations in the U.S. with record length $>20$ years. Large and diverse changes are occurring in datum levels at many ports. These imply both MSL rise (or vertical land movement) and changing tidal properties. The analysis emphasizes that planning and design studies for coastal structures should take into account possible changes in both factors. Moreover, results cannot be generalized between ports until the causes of tidal evolution are better understood. In this context, our study contributes to understanding an important sub-class of systems - those where navigational development and changes in river flow dominate recent changes in tidal properties.

Jay (2009) analyzed all long-term coastal tidal records from the eastern Pacific Ocean. There have been pronounced changes in tidal amplitudes coherent over thousands of kilometers, as well as smaller-scale changes related to local processes and harbor modifications. Large-scale evolution appears to be driven by shifts in the location of amphidromal points, but the reasons for such shifts are unclear. The increases in the $\mathrm{M}_{2}\left(77 \mathrm{~mm}_{\text {century }}{ }^{-1}\right)$ and $\mathrm{K}_{1}\left(35 \mathrm{~mm}\right.$ century $\left.{ }^{-1}\right)$ constituent amplitudes at Tongue Point in the Columbia are the second largest and largest, respectively, for any station in the eastern Pacific. These large changes in tidal amplitudes are likely related to navigational development in addition to larger-scale processes because the rate of change at Tongue Point is more than twice as large as at other nearby, less-developed harbors. 


\subsection{METHODS}

We consider here data sources, the theory on which our regression analyses is based, the regression analyses themselves, and the use of regression analysis results to construct hindcasts.

\subsection{DATA SOURCES}

The water level data analyzed here are taken from two stations with long records: Vancouver (1876-2009) and Tongue Point (1925-2009). Tides at Tongue Point represent the ocean tidal forcing, and water levels at Vancouver represent conditions in Portland and Vancouver harbors, near the landward end of the tidal river. A wooden staff gauge was installed at Fort Vancouver in 1876 by the U.S. Army Corps of Engineers. By 1902, it was under U.S. Weather Bureau control. The original wooden staff gauge was used until 1926, when it was replaced by another staff gauge. In 1958, the gauge was moved to a bridge 1.5 kilometers downstream from the original location.

The available Vancouver water-level record consists, prior to 1902, of an annual high water level (U.S. Army Corps of Engineers, Portland District, Sheet CL-03-116, 1973). Daily water levels (a single sample taken at 8 a.m. each day) are available from 1902 to 1971, except for a gap from mid-1905 to 1907. Recording of daily HHW, LLW and MWL commenced in October 1972 (www.nwd-wc.usace.army.mil/ perl/dataquery.pl?k= vancouver). Throughout the 1902-2009 record, all values apply to a 24 -hour solar day rather than a $\sim 25$-hour tidal day. Because this feature has been maintained over the entire time period, it has no effect on the analysis.

The Columbia tidal river has a mean slope of $O\left(10^{-5}\right)$, even during low-flow periods. Thus, a spatially varying, low-water datum is used, "Columbia River Datum" (CRD). CRD was defined in 1912 based on an extremely low tide, and water levels below CRD were, at that time, very unusual. Up to 1958 , the gauge zero was 0.244 meters $(0.8 \mathrm{ft})$ above CRD at Fort Vancouver, and the data have accordingly been corrected by that amount. Subsequent readings are on CRD. However, the CRD reference used is that for the original site. The actual CRD at the present site, 1.5 kilometers seaward of the historic location, is $\sim 0.03$ meters below CRD for the original site. This discrepancy is, however, quite small relative to the observed historical changes, and no corrections have been made.

The 1902-1971 recording at Vancouver of water level only once daily poses an analysis challenge. Fortunately, collection of a daily value at a fixed time randomizes the tidal phase over a 29-day period tidal month. Over a period of several years, the daily data will sample random tidal phases over the range of river-flow levels. Thus, even with daily sampling, MWL can be determined as a function of flow, given sufficient averaging time - each daily observation is regarded as a noisy but unbiased estimate of MWL corresponding to the flow of that day. The 26 annual high-flow values available for 1876-1901 are different. The dynamic range of these annual high-flow levels is too small to define MWL as a function of flow. All that can be determined 
is that these water levels are not inconsistent with early 20th century data. Even without the 1876-1901 data, Vancouver's 1902-2009 record is long by North American standards, and the datum level history at Vancouver is well documented.

The 1902-2009 daily record for Vancouver has been augmented by hourly data for November 1940 to August 1942 that was collected by NOAA. Daily MWL, LLW and HHW values were extracted from these data for consistency with the post-1972 Vancouver data.

Data from the NOAA reference tide gauge at Tongue Point were obtained for 1925-2009 from NOAA (http://tidesandcurrents.noaa.gov/products.html). The hourly data are nearly complete, except for an almost year-long gap in 1946-1947, about 3,500 bad data points in 1976-1977, and another 1,950 in 1983-1984. These gaps were filled using harmonic analysis (of the data from a nearby time period) and hindcasts based on the harmonic analysis. It was also necessary to hindcast Tongue Point tides for 1902-1924. This hindcast was based on harmonic analysis of 18.6 years of data, 1925-1943. The result was a complete 1902-2009 time series of hour heights, either observed or hindcast. Tongue Point GDTR was extracted on a daily basis. To determine extrema, the hourly data were spline interpolated to six-minute intervals. These values of GDTR were then used to force the models, as described below.

River flow strongly influences water levels - the spring freshet can raise the water level at Vancouver by as much as 10 meters, and high flows sharply reduce tidal range. Thus, river flow must be included in any analysis of Columbia River datum levels. The U.S. Geological Survey (USGS) daily Columbia River flow record from The Dalles, OR (at km-307) begins in 1878; the average flow at The Dalles is $\sim 97$ percent of that at Vancouver. USGS daily river-flow records for the Willamette River are complete from 1893 forward. Although Willamette River flows are usually much smaller than those of the Columbia, the Willamette enters below Vancouver. Its flow affects tidal dissipation and may backwater the mainstem beyond Vancouver. Thus, Willamette River flows need to be included as a separate input in analyses of Vancouver water levels. The Willamette River flows used here were routed from various more landward gauges to Portland before 1972, when the daily Portland flow record began.

\subsection{RIVER RIDES AND DATUM LEVELS -- THEORY}

Regression models are employed below to determine the decadal evolution of datum levels (LLW, MWL and HHW) as a function of the external forcing variables (river flow and ocean tides). The functional representation chosen for the models was derived from a theory of rivertide propagation (Jay, 1991) by KJ2003. There are three key non-dimensional parameters for convergent channels (Parker, 1988; Jay, 1991): a) nonlinearity $\varepsilon$ (ratio of tidal amplitude to mean depth); b) ratio of cross-sectional convergence rate to acceleration; and c) ratio of friction to acceleration. Our interest here is in the weakly non-linear case with $\varepsilon \sim 0.1$. In this situation, tidal amplitude, phase and the surface elevation minus current phase difference $\Delta$ are all controlled by a balance between tidal funneling (convergence) and friction. The asymptotic form of the wave equation for strong friction (acceleration $<<$ bed stress) is diffusive (LeBlond, 1978). The problem reduces to a first-order DE with only one (incident) wave, which diffuses rather than propagates. The reflected wave is insignificant except near reflecting barriers. Depending on the balance of friction and convergence, $0 \leq \Delta \leq 90^{\circ}$; but $\Delta \sim 45^{\circ}$ is common in river channels. 
The governing equations for tidal propagation contain several nonlinearities. In shallow channels, however, bed friction is the dominant one. KJ2003 use a two-fold strategy for simply modeling tidal behavior under these circumstances. First, an admittance (complex ratio of tidal response at any station to ocean tidal forcing) is formed and resolved into an amplitude ratio and a phase difference. (Only the amplitude ratio is used here, and ocean tidal forcing is expressed in terms of GDTR at the Tongue Point reference station, $\mathrm{T}_{R, \mathrm{TP}}$.) Second, the bed stress is expressed in terms of external parameters, the river flow $\mathrm{Q}_{\mathrm{R}}$ and $\mathrm{T}_{R, \mathrm{TP}}$.

The representation of the bed stress $\tau_{B}=\rho C_{D}|U| U$ term is key, because $\tau_{B}$ controls the complex wave number $q=k+(-1)^{1 / 2} r$ and, therefore, tidal propagation. Here, $\mathrm{U}$ is velocity, $\rho$ water is density, $\mathrm{C}_{\mathrm{D}}$ is the drag coefficient $k$ is the wave number, $r$ is the damping modulus. KJ2003 follows Dronkers (1964) in using a Chebyschev polynomial approach to representing $|\mathrm{U}| \mathrm{U}$ for the relevant case where tidal and fluvial flows are of similar magnitude and convergence moderate; these conditions yield $\Delta \sim 45^{\circ}$, with $k=-r$ and $q=\left((-1)^{1 / 2}-1\right) r$. Under these conditions, the KJ2003 models describe a constituent amplitude (or tidal range) ratio between a station of interest and a reference station near the ocean in terms of the damping modulus $r$ :

$$
\frac{\zeta[\mathrm{x}]}{\zeta_{\mathrm{TP}}}=e^{-i q\left(x-x_{\mathrm{TP}}\right)} \quad \log \left[\frac{|\zeta[\mathrm{x}]|}{\left|\zeta_{\mathrm{TP}}\right|}\right]=+r\left(x-x_{\mathrm{TP}}\right)
$$

where $\zeta[\mathrm{x}]$ is a tidal property (range or amplitude) at position $\mathrm{x}$, and $\zeta_{\text {TP }}$ is the same property at the reference station (Tongue Point), where $\mathrm{x}=\mathrm{x}_{\mathrm{TP}}$. KJ2003 use the Dronkers (1964) representation of $|\mathrm{U}| \mathrm{U}$ to parameterize (1b) in terms of external variables as:

$$
\log \left[\frac{\mid \zeta[\mathrm{x}]}{\left|\zeta_{\mathrm{TP}}\right|}\right]=\mathrm{a}_{0}+\mathrm{a}_{1} \mathrm{Q}_{\mathrm{R}}+\mathrm{a}_{2}\left(\frac{\mathrm{T}_{R, \mathrm{TP}}^{2}}{\mathrm{Q}_{\mathrm{R}}{ }^{\mathrm{n}}}\right) \text { with } n=\frac{1}{2}
$$

where $\left(x-x_{T P}\right)$ is assumed fixed and absorbed into the parameters.

Expressions like (1) can be used to describe tidal excursions from MWL (e.g., tidal amplitude or range). MWL (which is effectively the mean river stage) can also be modeled; KJ2003 used a linear form, again based on the Chebyschev expansion for $|\mathrm{U}| \mathrm{U}$ :

$$
M W L \approx b_{0}+b_{1} \mathrm{Q}_{R}^{2 / 3}+b_{2} \frac{\left(T_{\mathrm{R}, \mathrm{TP}}\right)^{2}}{Q_{\mathrm{R}}{ }^{n}} \text { with } n=\frac{4}{3}
$$

(In practice, KJ2003 added an atmospheric pressure term to (2) that is neglected here.) How then can a quantity be parameterized that combines river stage and tidal properties (e.g., LLW=MWL $-1 / 2$ GDTR)? A pragmatic approach is needed, one that bridges the difference between the logarithmic and linear forms of (1c) and (2). Also, a linear form must be used at least for LLW because LLW has negative values. The key is a property of the natural log function:

$$
\log [1+\delta]=\delta \quad \operatorname{limit} \delta \rightarrow 0
$$

For amplitude ratios near unity, the departure, $\delta$, of the ratio in (1a) from unity may be modeled linearly. In fact, the amplitude departures are always negative (tides are smaller at Vancouver 
than at Tongue Point), and the ratio of tidal amplitudes is sometimes small ( $|\delta|$ approaches 1$)$. In this respect, it is the linear model for MWL that saves the validity of models like (1) for LLW and HHW - if $\mathrm{Q}_{\mathrm{R}}$ is large and range small, the HHW and LLW models are only a small perturbation of the linear MWL model. Thus, a linear model is appropriate in both the low flow ( $\delta$ small) and high flow $(|\delta| \sim 1)$ limits.

\subsection{RIVER TIDES AND DATUM LEVELS -- PRACTICAL REGRES- SION MODELS}

The above considerations suggest datum level models of the form:

$$
\begin{aligned}
& \mathrm{LLW}=\mathrm{a}_{0 \mathrm{k}}+\mathrm{a}_{1 \mathrm{k}} \mathrm{Q}_{\mathrm{TD}}{ }^{m}+\mathrm{a}_{2 \mathrm{k}} \mathrm{Q}_{\mathrm{WR}}{ }^{m}+\mathrm{a}_{3 \mathrm{k}}\left(\frac{\mathrm{T}_{R, \mathrm{TP}}^{2}}{\left(\mathrm{Q}_{\mathrm{TD}}+\mathrm{Q}_{\mathrm{WR}}\right)^{\mathrm{n}_{1}}}\right) \\
& \mathrm{HHW}=\mathrm{b}_{0 \mathrm{k}}+\mathrm{b}_{1 \mathrm{k}} \mathrm{Q}_{\mathrm{TD}}{ }^{m}+\mathrm{b}_{2 \mathrm{k}} \mathrm{Q}_{\mathrm{WR}}{ }^{m}+\mathrm{b}_{3 \mathrm{k}}\left(\frac{\mathrm{T}_{R, \mathrm{TP}}^{2}}{\left(\mathrm{Q}_{\mathrm{TD}}+\mathrm{Q}_{\mathrm{WR}}\right)^{\mathrm{n}_{2}}}\right) \\
& \mathrm{MWL}=\mathrm{c}_{0 \mathrm{k}}+\mathrm{c}_{1 \mathrm{k}} \mathrm{Q}_{\mathrm{TD}}{ }^{m}+\mathrm{c}_{2 \mathrm{k}} \mathrm{Q}_{\mathrm{WR}}{ }^{m}+\mathrm{c}_{3 \mathrm{k}}\left(\frac{\mathrm{T}_{R, \mathrm{TP}}^{2}}{\left(\mathrm{Q}_{\mathrm{TD}}+\mathrm{Q}_{\mathrm{WR}}\right)^{\mathrm{n}_{3}}}\right)
\end{aligned}
$$

Where:

$$
\begin{array}{ll}
\mathrm{Q}_{\mathrm{TD}} & =\text { Columbia River flow at The Dalles, } 1,000 \mathrm{~s} \mathrm{of} \mathrm{m}^{3} / \mathrm{s} \text {, lagged } 1 \text { day } \\
\mathrm{Q}_{\mathrm{WR}} & =\text { Willamette River flow at Portland, } 1,000 \mathrm{~s} \mathrm{of} \mathrm{m}^{3} / \mathrm{s} \\
\mathrm{T}_{R, \mathrm{TP}} & =\text { GDTR }(\mathrm{m}) \text { at Tongue Pt } \\
\mathrm{a}_{\mathrm{ik}} \text { to } \mathrm{c}_{\mathrm{ik}}, \mathrm{i}=1,4 & =\text { Model parameters for each station } \\
\left\{\mathrm{n}_{1}, \mathrm{n}_{2}, \mathrm{n}_{3}\right\} & =\text { tide-flow interaction exponents; }\left\{\mathrm{n}_{1}, \mathrm{n}_{2}, \mathrm{n}_{3}\right\}=\{0.5,1.5,1.333\} \\
\mathrm{k} & =\text { index for time periods, } \mathrm{k}=1,21 \\
\mathrm{~m} & =\text { flow exponent; } \mathrm{m}=1
\end{array}
$$

The first three terms in each of (3) to (5) relate tidal datum levels to river flows $Q_{\mathrm{TD}}$ and $\mathrm{Q}_{\mathrm{WR}}$ (all flows are positive). $Q_{\mathrm{TD}}$ and $\mathrm{Q}_{\mathrm{WR}}$ are included separately in (3) to (5), so that $Q_{\mathrm{TD}}$ could be lagged one day, due to the 80 kilometer distance between The Dalles and Vancouver. Though including two flow values adds a regression parameter and increases error bounds, it makes the model more effective in representing high flows.

The assumption (from KJ2003) that river flow should appear linearly in (3) to (5) simplifies the actual nonlinear response of tidal parameters to river flow $Q_{R}$ (where $Q_{R}$ is either $Q_{\mathrm{TD}}$ or $\mathrm{Q}_{\mathrm{WR}}$ ). 
To reduce the number of free parameters, KJ2003 approximated the function $\alpha_{1} Q_{R}{ }^{1 / 2}+\alpha_{2} Q_{R}{ }^{3 / 2}$ in Jay (1991) by $\alpha Q_{R}{ }^{\mathrm{m}}$, with $\mathrm{m}=1$. In principal, $\alpha_{1}$ and $\alpha_{2}$ depend on the ratio of $Q_{R}$ to the total current, and both $Q_{\mathrm{TD}}, \mathrm{Q}_{\mathrm{WR}}$ and $\mathrm{T}_{R, \mathrm{TP}}$ have all changed, so $\mathrm{m}$ might be expected to vary over time. If, however, $m$ is treated as a parameter to be determined by iteration, it fluctuates with the dynamic range of $Q_{R}$. The sharp reduction in dynamic range of Columbia River flow since 1970 then causes $m$ to increase artificially after 1970. Based on experimenting over the range of $1 / 2 \leq \mathrm{m} \leq 1 \frac{1}{2}$, we set (following KJ2003) $\mathrm{m}=1$. This expedient has only a minor effect on the results. It does, however, prevent use of models for recent time periods to hindcast water levels for the highest historic flow levels (i.e., those that no longer occur because of flow regulation).

The last term in each of (3) to (5) represents the effects of the nonlinear interaction of tides and river flow. This interaction is quadratic in $\mathrm{T}_{R, \mathrm{TP}}$, but its importance decreases as river flow increases. Because LLW=MWL-1/2GDTR and HHW=MWL $+1 / 2$ GDTR are influenced by both stage and tidal range, and $\mathrm{n}$ is different in (1c) and (2), an empirical procedure was used to determine the exponents $\left\{\mathrm{n}_{1}, \mathrm{n}_{2}, \mathrm{n}_{3}\right\}$. Iterative regression analyses were run for representative time periods with $n_{j}(j=1,3)$ varying over $0.5 \leq n_{j} \leq 1.5$ in steps of 0.1666 to find the optimal exponent for each datum level and time period. A final value was chosen for each datum that represented datum level behavior reasonably well over all these time periods.

The processes represented by the tidal-fluvial interaction term in (3) to (5) are spatially variable. Near the ocean, GDTR is large, and tidal monthly changes in stage due to frictional interactions are small; thus, $c_{3}<0$, so that LLW decreases on spring tides. At upriver locations like Vancouver, GDTR is small, and tidal monthly storage is substantial, because stronger tides require a larger slope to discharge the same river flow. Here, LLW decreases on neap tides, $c_{3}>0$, and the lowest LLW values occur on neap tides during the low-flow season, when the tidal monthly effect is maximal. In fact, the tidal monthly effect is so large at Vancouver (relative to the local tidal range) that all three coefficients $\left(a_{3}, b_{3}, c_{3}\right)$ are typically $>0$.

The coefficients $a_{i k}$ to $c_{i k}(i=1,4, k=1,21)$ in (3) to (5) were determined by robust multiple linear regression analyses (Huber, 1996; Leffler and Jay, 2009) to best fit the observations, with a different set of coefficients determined for each time period. The robust method is also known as iteratively re-weighted least-squares regression (IRLS). IRLS iteratively down-weights outliers to achieve a more accurate result with tighter confidence limits. One departure from robust linear regression was used. Extremes of tidal range and river flow are rare, but these data are vital in determining the behavior of tidal datum levels for extreme forcing conditions. Data points were accordingly weighted by an analytical function that approximated the inverse square root of their frequency of occurrence. This weighting was applied along with the IRLS re-weighting, so that the total weight on each data point in each iteration was the product of the river-flow/range weight with the IRLS weight. The weighted $\mathrm{R}^{2}$ values for regressions of datum levels LLW, HHW and MWL using (3) to (5) were always $>0.95$.

Quantifying the time evolution of tidal properties implies defining models for time periods that are short relative to the total length of record. Accordingly, separate analyses are carried out for overlapping 10-year periods, with mid-points separated by five years. There were several exceptions to the usual 10-year overlapping periods used to model tidal parameters. For MWL, the first time interval is 1902-1910, with a gap from 1905-1907. The periods 1986-1995 and 2001- 
2009 were singularly lacking in high-flow data. Taking advantage of very high flows in 19961997, the periods 1986-1997 and 1997-2009 were used in models of all three parameters to provide better dynamic range in river flow. LLW and HHW are available only for 665 days in 19401942, and after October 1972. The first time period for these parameters extends from 19401942, and the second from 1972-1980.

\subsection{HINDCASTS}

The daily data available before 1972 are sufficient to allow formation of MWL models using (5), but do not directly provide MWL on a daily basis, a tabulation needed for understanding historical changes. Thus, hindcasts of daily MWL were prepared for 1902-2009. Vancouver HHW and LLW data are available for 1940-1942 and 1972-2009 only. It is not reasonable, therefore, to hindcast these tidal properties back to 1902. HHW and LLW hindcasts were extended back to 1925 for two reasons: a) the Tongue Point record starts in 1925, and b) the driest period in the last 150 yrs in the Columbia Basin began about 1925 (Naik and Jay, 2005), making this a good starting point for evaluation of present low-water levels. The models based on the 1940-'42 data were used from 1925 to mid-1958. The 1972-80 models were used from mid-1958 to mid-1976. Thereafter, each model was used for the central five to seven years of its validity, except for the last model for each parameter, used up to 2009. 


\subsection{RESULTS}

We present here typical results, long-term trends (1902-2009), changes in the LLW, MWL and HHW datum levels, and changes in the incidence of very low waters, which are of great concern for navigation.

\subsection{TYPICAL RESULTS}

Model results for LLW for October 1972 to 1980 are typical (Figure 4.1). The histogram in Figure 4.1 a shows that this time period provides a dynamic range of $\mathrm{Q}_{\mathrm{TD}}$ from $\sim 1,500$ to $16,600 \mathrm{~m}^{3} \mathrm{~s}^{-}$ 1 . This flow range reflects a high flow year (1974) and two very low-flow years (1973 and 1977). The highest flows are lower than for most time periods before 1970, but higher than after 1980 . Figure $4.1 \mathrm{~b}$ displays the modeled LLW behavior as a function of $\mathrm{Q}_{\mathrm{TD}}$ for $\mathrm{Q}_{\mathrm{TD}}=1,500$ to $20,000 \mathrm{~m}^{3} \mathrm{~s}^{-1}$ over the full range of observed $\mathrm{T}_{R, \mathrm{TP}}$ values; $\mathrm{Q}_{\mathrm{WR}}$ values are typical for each $\mathrm{Q}_{\mathrm{TD}}$. Also shown are the data, which emphasize the broad range of LLW values that can occur for low to moderate $\mathrm{Q}_{\mathrm{TD}}$ values. The largest positive departures of the data in Figure 4.1b from the model represent $\mathrm{Q}_{\mathrm{WR}}$ flows above the values assumed. It is evident from Figure 4.1c that there is an adequate fit to the data over the entire range of LLW waters, reflecting the $\mathrm{R}^{2}$ of 0.986 . Figure $4.1 \mathrm{~d}$ shows time series of data, hindcasts and residuals (modeled-observed). There are residuals of $\sim 0.5$ meters for very high-flow periods with a systematic underestimation of the maximum values of LLW. This issue arises in part from the limited very high-flow data, but also from setting the flow exponent to unity in (3). Errors for low-flow periods are smaller, and the RMS error for $1972-1980$ is 0.20 meters. 


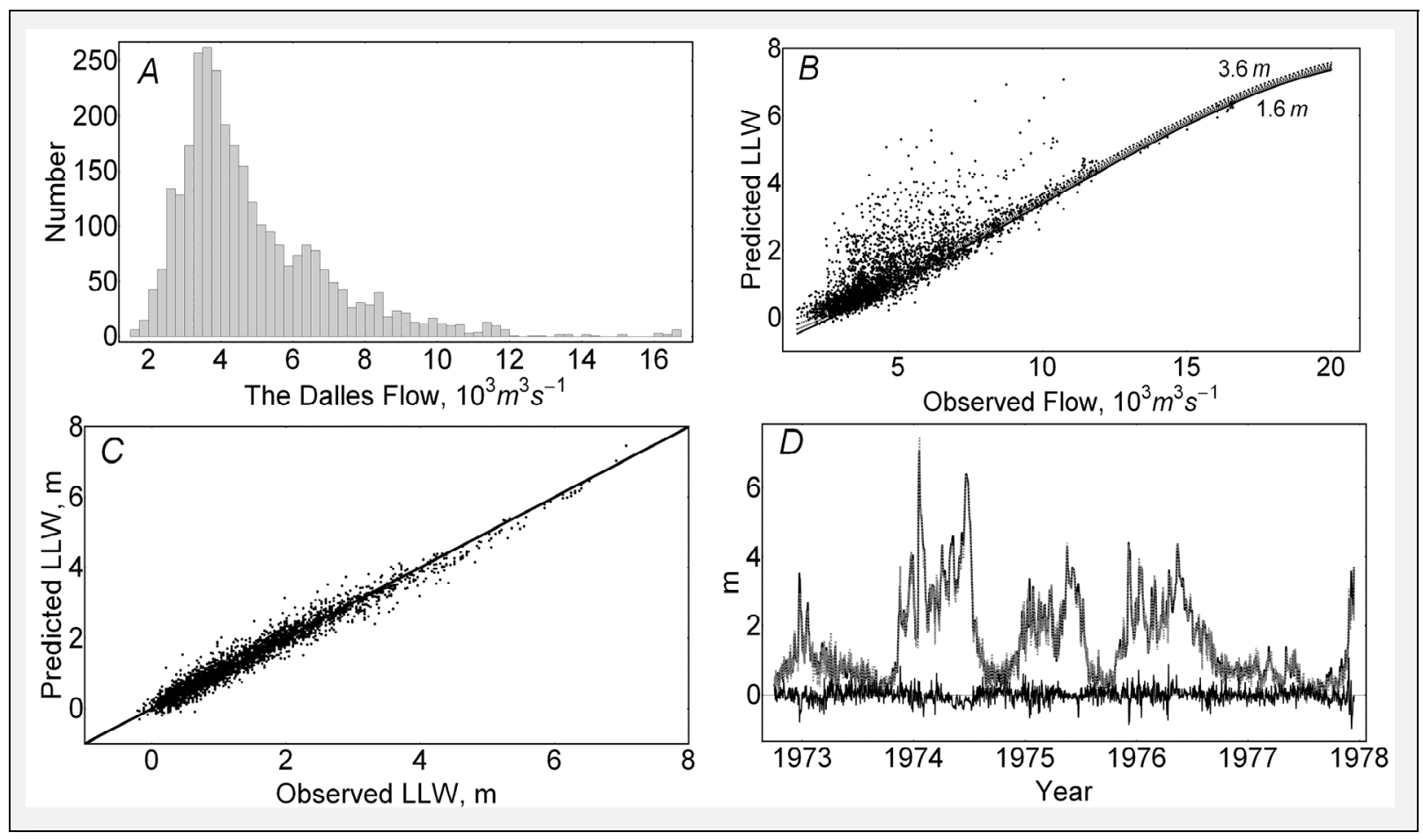

Figure 4.1: Vancouver LLW model results for 1972-1980: a) histogram of $\mathrm{Q}_{\mathrm{TD}}$, b) daily LLW in $\mathrm{m}$ vs. $\mathrm{Q}_{\mathrm{TD}}$, with a line representing the modeled LLW vs. flow for five values of $\mathrm{T}_{R, \mathrm{TP}}$ from (bottom to top) 1.6 to $3.6 \mathrm{~m}$ (the nonlinearity of the curves is related to varying $\mathrm{Q}_{\mathrm{WR}}$ ), c) modeled vs. observed LLW, both in $\mathrm{m}$, with the 1:1 line, and d) observed (solid) and modeled (dotted) LLW and the residual error for October 1972 to December 1978, encompassing very low-flow $(1973,1977)$ and very high-flow (1974) water years.

\subsection{LONG-TERM TRENDS, 1902-2009}

Figure 4.2 shows HHW, MWL and LLW hindcasts for six QTD values from 2000 to $12,500 \mathrm{~m}^{3} \mathrm{~s}^{-1}$, all for an average $\mathrm{T}_{R, \mathrm{TP}}=2.6 \mathrm{~m}$. Results are confined to this range of flows because some time periods lack the very low and high flows needed to form valid models for more extreme flows. For QTD from 2500 to $7500 \mathrm{~m}^{3} \mathrm{~s}^{-1}$, there is a nearly monotonic decrease in all datum levels over time. For $\mathrm{Q}_{\mathrm{TD}}<2500 \mathrm{~m}^{3} \mathrm{~s}^{-1}$, there is a maximum in the MWL curve at $\sim 1970$. Because there are LLW and HHW data before 1972 only for 1940-1942, it is impossible to determine whether LLW and HHW showed a similar anomaly. This feature could be a response to pile dike construction between 1970 and 1975. For $\mathrm{Q}_{\mathrm{TD}}>7,500 \mathrm{~m}^{3} \mathrm{~s}^{-1}$, there is a 1930-1935 maximum in MWL that may correspond to pile dike construction prior to channel deepening ca. 1935. Finally, for all flow levels, there a divergence over time of the HHW and LLW levels, reflecting an increase in tidal range. 


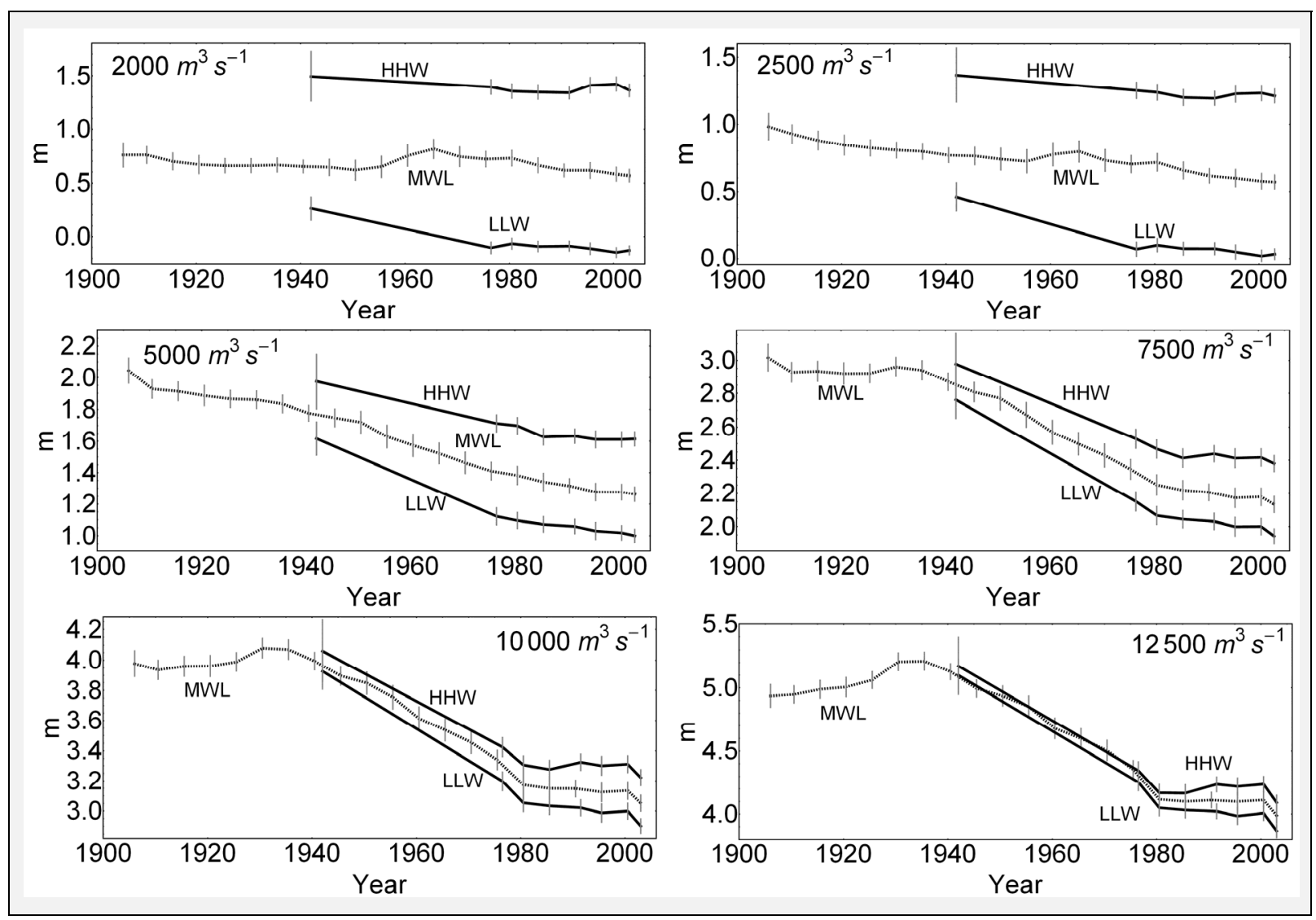

Figure 4.2: Modeled values of Vancouver (top to bottom in each panel) HHW, MWL and LLW for all periods for $\mathrm{Q}_{\mathrm{TD}}=2,500$ to $12,500 \mathrm{~m}^{3} \mathrm{~s}^{-1}$ (as indicated), and an average $\mathrm{T}_{R, \mathrm{TP}}=2.6 \mathrm{~m}$; $\mathrm{Q}_{\mathrm{WR}}=100$ for $\mathrm{Q}_{\mathrm{TD}}=2,000$ and $2,500 \mathrm{~m}^{3} \mathrm{~s}^{-1}$, otherwise, $\mathrm{Q}_{\mathrm{WR}}=250 \mathrm{~m}^{3} \mathrm{~s}^{-1}$. Also shown are 95 percent confidence limit bars centered on the time of each period for which data are available. Each error bar is placed at the central point of the corresponding 10-year period. No HHW and LLW data are available between 1942 and 1972.

\subsection{CHANGES IN LLW AND HHW DATUM LEVELS AS A FUNCTION OF FLOW AND RANGE}

The most important issue for navigation is the increase in the incidence of LLW levels near or below CRD during fall low-flow periods. For salmon habitat restoration, the decrease in HHW levels during the spring freshet period is critical. We show, therefore, modeled Vancouver LLW and HHW for two $\mathrm{Q}_{\mathrm{TD}}$ values $\left(2,500\right.$ and $\left.7,500 \mathrm{~m}^{3} \mathrm{~s}^{-1}\right)$, each for five $\mathrm{T}_{R, \mathrm{TP}}$ values, 1.6, 2.1, 2.6, 3.1 and 3.6m; $\mathrm{Q}_{\mathrm{WR}}=100 \mathrm{~m}^{3} \mathrm{~s}^{-1}$ (Figure 4.3). LLW has decreased more rapidly than HHW for all flow and Tongue Point GDTR values, increasing tidal range. Interestingly, $\mathrm{T}_{R, \mathrm{TP}}$ has a much stronger influence on HHW than LLW during low flows, but the reverse is true for high flows. The drop in $\mathrm{LLW}$ for $\mathrm{Q}_{\mathrm{TD}}=2,000 \mathrm{~m}^{3} \mathrm{~s}^{-1}$ and $\mathrm{T}_{R, \mathrm{TP}}<2.6 \mathrm{~m}$ has been $0.37 \mathrm{~m}$ (not shown). Hindcast changes for $\mathrm{Q}_{\mathrm{TD}}=2,500 \mathrm{~m}^{3} \mathrm{~s}^{-1}$ are slightly larger: $0.41-0.49$ meters. In contrast, changes in HHW water are small for low-to-average $\mathrm{Q}_{\mathrm{TD}}\left(2,500-7500 \mathrm{~m}^{3} \mathrm{~s}^{-1}\right)$, within the 95 percent confidence limits of the 1940 -' 42 data. Only for higher flows is there a substantial drop in HHW. For $\mathrm{Q}_{\mathrm{TD}}=10,000 \mathrm{~m}^{3} \mathrm{~s}^{-1}$, 
and $\mathrm{T}_{R, \mathrm{TP}}>2.6 \mathrm{~m}$, HHW has dropped 1-1.1 meters. For $\mathrm{Q}_{\mathrm{TD}}>12,500 \mathrm{~m}^{3} \mathrm{~s}^{-1}$, the drop is $>1.5$ meters for some combinations of flow and Tongue Point tides.

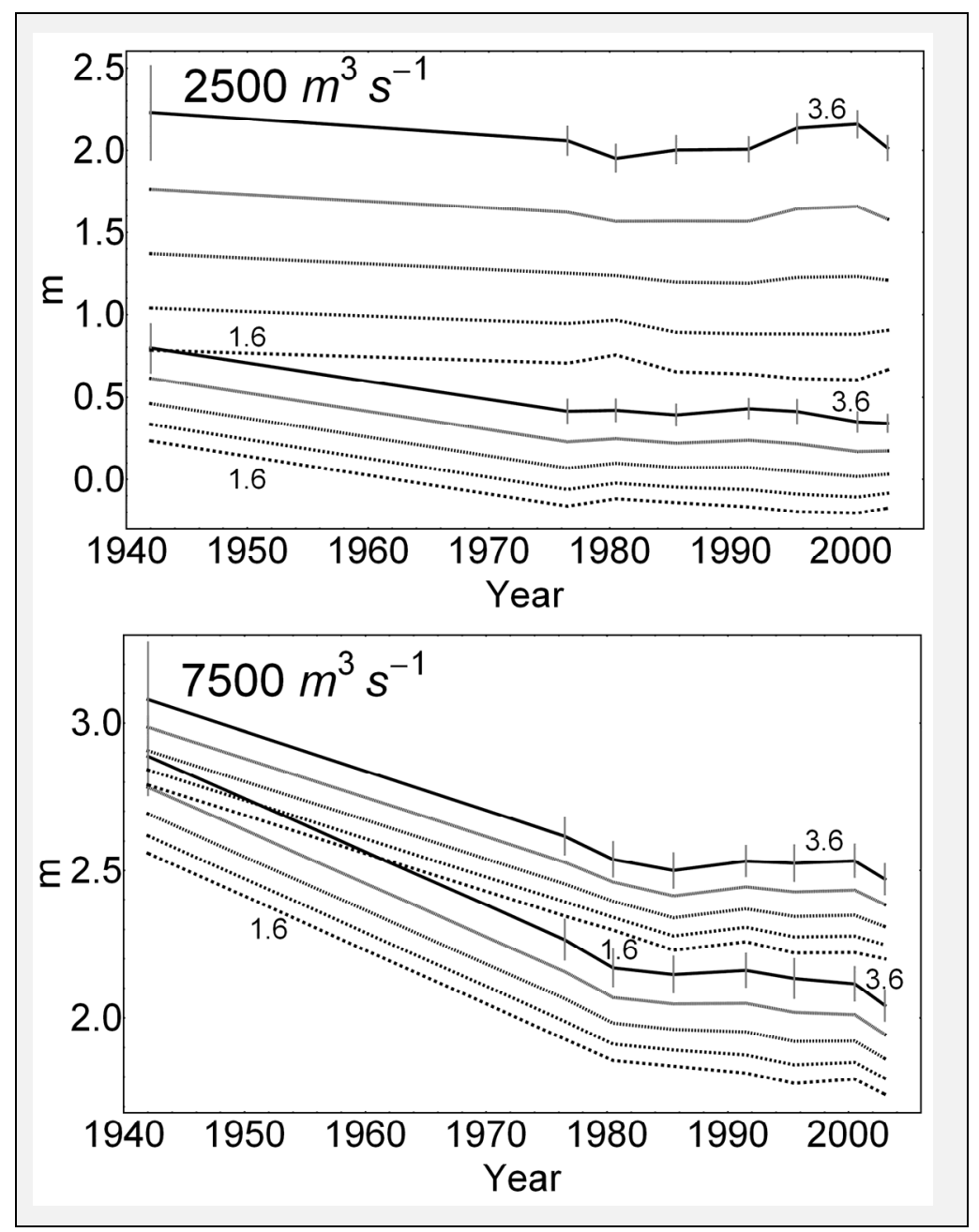

Figure 4.3: Modeled values of Vancouver HHW (above) and LLW (below) for $\mathrm{Q}_{\mathrm{TD}}=2,500$ and $7,500 \mathrm{~m}^{3} \mathrm{~s}^{-1}$, each for five values of $\mathrm{T}_{R, \mathrm{TP}}$ (top to bottom): 3.6, 3.1, 2.6, 2.1, and $1.6 \mathrm{~m} ; \mathrm{Q}_{\mathrm{WR}}=100 \mathrm{~m}^{3} \mathrm{~s}^{-1}$. For clarity, only 95 percent confidence limits are shown only for HHW and LLW for $\mathrm{T}_{R, \mathrm{TP}}=3.6 \mathrm{~m}$; other error bars would be smaller. Each error bar is placed at the central point of the corresponding 10 -year period.

The different situations for LLW and HHW can be interpreted as follows: Increasing $\mathrm{T}_{R, \mathrm{TP}}$ values and dropping MWL values (Figure 4.2) both cause Vancouver LLW to decrease. In contrast, increasing GDTR values tend to raise HHW, whereas lower MWL values tend to decrease HHW. For low flows, these two contrary influences on HHW are almost in balance. At higher flows, the drop in MWL outweighs changes in GDTR because GDTR at Vancouver is (and always has been) small relative to changes in MWL related to the annual flow cycle. Thus, long-term changes in MWL control variations in HHW during high flow levels. 


\subsection{CHANGES IN THE INCIDENCE OF VERY LOW WATER LEVELS}

Long-term changes in the occurrence of very low water levels are summarized in Figure 4.4, which shows the hindcast (1925-2009) and observed (1972-2009) number of days per year with LLW below the critical values of $0.0,0.1,0.2$ and 0.5 meters on CRD. The number of days with $\mathrm{LLW} \leq 0.2 \mathrm{~m}$ CRD (Figure 4.4) and MWL $\leq 0.5 \mathrm{~m}$ CRD (Figure 1) during dry years has increased substantially since 1977. Compared to 1925-1946, there are now many fewer low-flow days and fewer days with small $\mathrm{T}_{R, \mathrm{TP}}$ (factors associated with low water levels), but more days with very low water levels. Since 2000, the number of days with $L L W \leq 0.0-0.5 \mathrm{~m}$ and MWL $\leq 0.5-1 \mathrm{~m}$ has increased in a manner that does not reflect river flow or tidal forcing. It is likely, therefore, that this change reflects changes in system hydraulics and/or bed configuration.

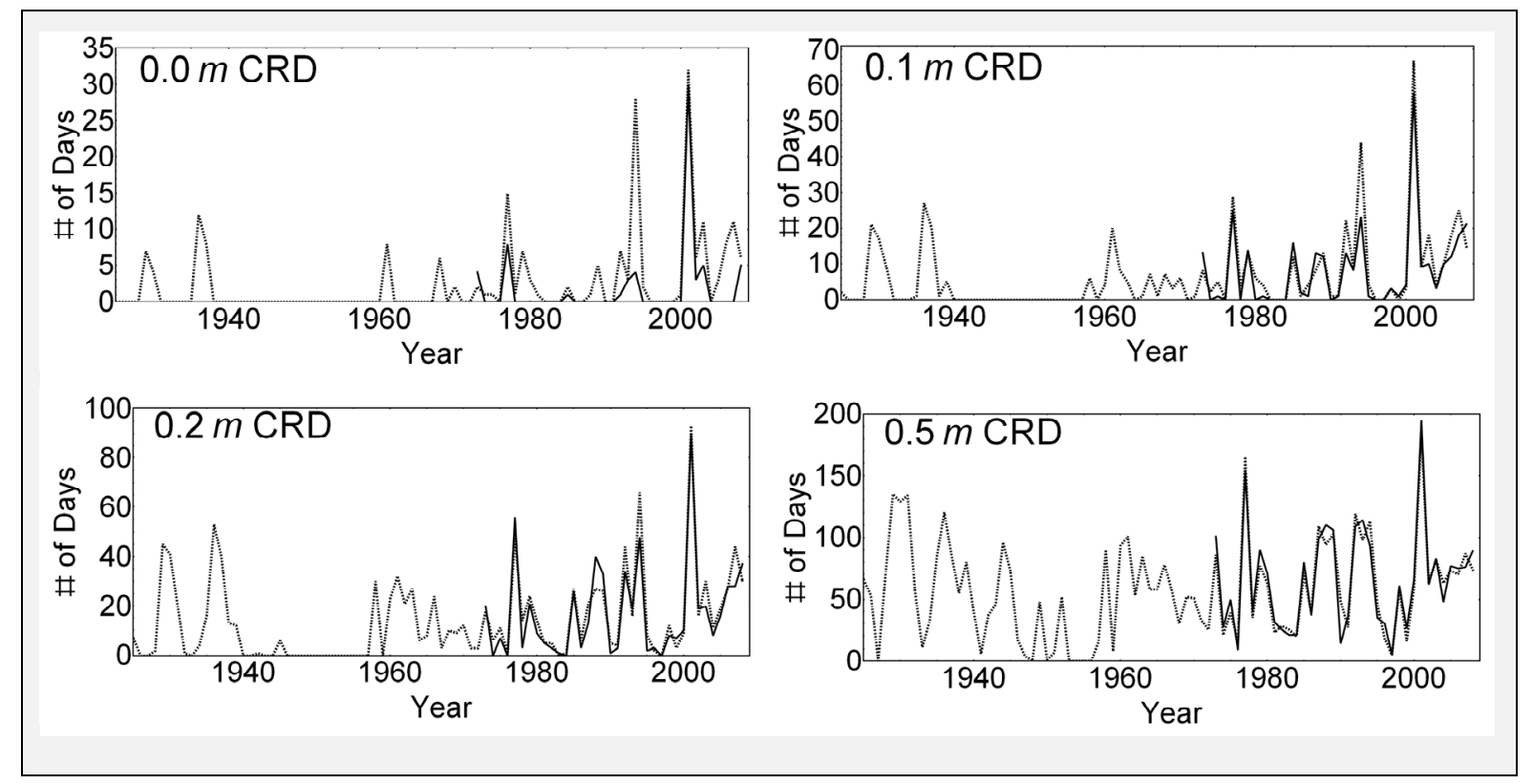

Figure 4.4: Hindcast (1925-2009, dotted) and observed (1973-2009, solid) number of days per year on which the LLW at Vancouver was less than the specified value.

The comparison of observed and hindcast values for 1972-2009 in Figures 1 and 6 also provides a good overview of model success. The model accurately reflects the number of days per year with MWL $\leq 0.5-1 \mathrm{~m}$ and $L L W \leq 0.1-0.5 \mathrm{~m}$ on CRD. The hindcast number of days with $L L W \leq 0.0 \mathrm{~m}$ on CRD is too large, likely because the small number of days with very low flows in recent decades limits the ability of the LLW model (3) to represent these conditions. 


\subsection{DISCUSSION}

It remains to consider the significance, likely causes and possible future course of tidal evolution in the Columbia, and the implications for other river ports.

\subsection{SIGNIFICANCE AND CAUSES}

The decreases in LLW and MWL between 1940 and 2009 were 0.37-0.49 meters and 0.2-0.28 meters, respectively, for $\mathrm{Q}_{\mathrm{TD}}$ values of $2,000-2,500 \mathrm{~m}^{3} \mathrm{~s}^{-1}$ and $\mathrm{T}_{R, \mathrm{TP}}$ values $\leq 2.6 \mathrm{~m}$. Decreases in HHW are $>1.3 \mathrm{~m}$ at $12,500 \mathrm{~m}^{3} \mathrm{~s}^{-1}$, the highest flow that can be examined with the models used here. Vancouver GDTR is increasing for all combinations of tidal and fluvial forcing. The decreases in water levels have been most rapid for the high flows that affect salmon habitat and slowest for the low flows that are of significance to navigation. Nonetheless, changes are ongoing, even at the lowest contemporary flow levels, $1,500-2,000 \mathrm{~m}^{3} \mathrm{~s}^{-1}$. Similar changes are seen at other more stations seaward to 67 kilometers, and the situation at Vancouver is typical for the tidal river as a whole.

The significance of these historic changes for navigation can be put into perspective relative to the recent channel deepening from 12.2 to 13.1 meters, constructed at a cost of $\$ 199$ million. The ongoing loss in low-flow water levels since 1940 has been about half this increase in depth in the summer-fall low-flow season, and larger the rest of the year. Clearly these changes are significant to navigation because they are expensive to remedy and increase the incidence and duration of low-water transits. The importance of the observed elevation changes for juvenile salmon can be judged from changes in shallow-water habitat for a reach between 54 and 85 kilometers (KJ2003). About 60-75 percent of this habitat is no longer accessible in the spring due to diking and flow regulation; diking is the primary factor. In most years, the lower water levels documented here significantly exacerbate the reduction of habitat available to juvenile salmonids because there is less habitat area at the water levels now reached in spring than at historic levels that covered the floodplain.

There are several possible causes for the changes in water levels documented here. One likely cause is a decrease in total roughness of the channel, which would affect both MWL and GDTR. Beach nourishment, pile dikes and channel construction reduce the drag associated with sinuousity and irregular banks, and regular dredging reduces drag associated with bed forms. Channelization of the flow into a narrower, deeper channel is another factor likely to alter tides. Doubling depth while halving the momentum-conveying width (a change that approximates the historic changes in many parts of the system) will increase tidal amplitude by a factor of $2^{1 / 4} \cong 1.19$ in a low-friction channel (Jay, 1991). While the Columbia is not a low-friction system, this is still a likely factor causing changes to the tidal regime. Because of the analysis method and because adjustments in channel configuration occur incrementally over several decades rather than immediately after construction of a deeper channel, it is not possible to connect changes in the tides to any specific channel deepening, but there is little doubt that the two are connected. 
Bed degradation, due to reduced sand supply, dredging and sand mining, may have lowered water levels. The reservoir system has decreased sand supply by $\sim 80$ percent (Bottom et al., 2005) from $\sim 14 \times 10^{6}$ metric tons year ${ }^{-1}$ before 1900 to $2.2-3 \times 10^{6}$ tons year $^{-1}$ since 1970 . Also, $\sim 3-$ $5 \times 10^{6}$ tons year ${ }^{-1}$ of sand have been removed each year in recent decades for channel maintenance, sand mining and shoreline development. Lack of sand supply from the river is one factor that has caused degradation of the bed near the ocean entrance and damage to the entrance jetties. It is not presently known whether there has been a systematic degradation of the bed in the vicinity of Vancouver, but sand removal and trapping of sand by the reservoir system clearly creates a tendency toward bed degradation and reduced water levels.

Changes in external forcing are also important. Tidal amplitude has increased at Tongue Point due to growing ocean tides. This has reduced the incidence of very low MWL levels at Vancouver. Climate change and water withdrawal have caused average annual Columbia River flow to decrease 17 percent since 1900 (Naik and Jay, 2010). While decreased river flows increase tidal range and decrease water levels, flow regulation has actually reduced the incidence of very lowflow days (Figure 1). Moreover, the changes described here are for fixed flow. Thus, reduced flows are not the direct cause of these changes, though smaller freshets help maintain the engineered, low-friction environment by reducing bank erosion, snag movement, growth of sand waves, and bar creation. Future decreases in flow may, however, drive further decreases in water levels.

Several other factors may contribute to future changes in water levels. Climate change scenarios are divided as to whether Columbia Basin precipitation will increase or decrease in the future, but there is broad agreement that temperatures are increasing, yielding (in the absence of altered flow regulation) higher winter and lower summer river flows (Hamlet and Lettenmaier, 2007). Absent flow management to support fall flows, we may see, in future dry years, low-flow periods comparable to those that occurred in dry years before 1940 (cf. Figure 1.1) with resultant extended periods of low water levels. Climate change scenarios do not provide much guidance as to whether future sediment supply will decrease or increase. Without reversal of the imbalance between sediment supply and removal, however, a degradation of the bed must be considered at least a likely possibility, one that could contribute to lower water levels during low-flow periods by further reducing friction in the system.

Tectonics may also influence water levels. The relative MSL rate of change at Tongue Point is near zero (Jay, 2009) - tectonic and regional sea level changes are closely balanced. In absolute terms, however, the coast is rising at 0.1-0.2 meters per century ${ }^{-1}$ and Vancouver is falling at 0.05-0.1 meters per century ${ }^{-1}$ (Mote et al., 2008). Thus, the rise of coastal waters relative to Vancouver is $0.15-0.3$ meters per century ${ }^{-1}$. This suggests that the observed fall in MWL at Vancouver would actually have been considerably larger without regional tectonic motion.

\subsection{POSSIBLE FUTURE CHANGES}

The above information allows informed speculation regarding the possible course of future changes in water levels in the more landward part of the system. In principle, decreases in fluvial water levels are self-limiting because a net slope is required to discharge the substantial river flow of the system. CRD at Vancouver (km-178) is $\sim 1.5$ meters above MLLW at Tongue Point 
(km-30), yielding is an average slope of $\sim 10^{-5}$. A decrease of this low water slope of 20 percent would cause a further drop of $\sim 0.3$ meters in low-flow water levels. While it is unclear whether such decreases will occur, it is difficult, given the history of the system, to exclude this possibility. Whatever changes occur in channel properties, dropping water levels may be ameliorated to some extent by tectonic effects. Still, it is possible that, without some change in river-flow levels or sediment management, decreases in water levels will continue for some decades.

\subsection{IMPLICATIONS FOR OTHER RIVER PORTS}

In summary, there are two broad causes of tidal evolution in the Columbia: changes in coastal tides and human modification of the river system. The latter includes alteration of system topography and sand removal, but also flow regulation and diversion. At this point, tidal evolution is understood in this system as well as for any river port, but we are still not able to quantify the role of the various system alterations or suggest specific management options to halt the decrease in water level. Further work is needed, including analysis of other tidal records and numerical modeling of sediment transport under a variety of management scenarios.

Amin (1983) implies dual causation of tidal changes in the Thames, similar to that in the Columbia. This appears to be a general pattern throughout Northern Europe for those harbors where rapid tidal evolution is occurring. In this context, the Columbia is by no means an extreme or isolated example. Changes on the U.S. East Coast and in some European systems are larger, and similar processes, not yet documented, may be occurring in other heavily modified North American river ports. Other analyses have not, however, quantified the role of river flow in controlling water levels. They have instead focused on navigational development and neglected the possible role of water diversion and other forms of flow manipulation in observed tidal evolution. Tectonic impacts have also been given little consideration.

Future impacts of climate change on ports need to be evaluated in the context of the multiple factors affecting the tidal regime of river ports. A warmer climate may influence tides through MSL rise, but also through changes in ocean density stratification and coastal circulation. Climate change is also altering the hydrologic regime (flows and sediment transport) of the Columbia and other major river systems. Both the direct effects of climate and those of the human response to climate change in the form of manipulation of the flow cycle will be felt downstream, in the tidal regimes of river ports. 


\title{
APPENDIX A
}

\section{DRAFT PAPER: \\ TOWARD A SAND BUDGET FOR THE LOWER COLUMBIA RIVER}

\author{
by
}

William J Templeton

David A Jay 


\title{
Toward a Sand Budget for the Lower Columbia River
}

\author{
by \\ William J Templeton \\ David A Jay
}

Department of Civil and Environmental Engineering

Portland State University

PO Box 751

Portland, OR 97207 USA

To be submitted to:

ASCE Journal of Waterway, Port, Coastal, and Ocean Engineering

Subject Headings: Littoral deposits; sediment transport; dredging; navigation; Columbia River 


\begin{abstract}
Long-term changes in the sand balance of a river-estuary system may have profound consequences for both navigation and ecosystem processes. Here, we examine the balance of sand input by fluvial supply vs. human removal in the Lower Columbia River (LCR). Estimates of sand input from the three largest fluvial sources of sand were used to calculate the input side of the sand budget for the system: Columbia River at Vancouver, Willamette River at Portland, and Cowlitz River at Castle Rock. Sand transport rating curves were developed for all three rivers and used to estimate the daily sand input into the LCR. Numerous publications, interviews and studies were used to evaluate the extent of sand removal by dredging for navigation and fill, and sand mining from the LCR; two different dredging removal scenarios were considered, 41 percent and 50 percent removal rates. Sand export to the ocean could not be estimated, but is assumed to be small for the present, managed flow regime. Comparison between the sand inputs and outputs indicate that a sand deficit has consistently existed in the LCR since the 1970s, with the exception of the period after Mt. St. Helens' eruption. Since the St. Helens eruption, this deficit has been five megatons per year ${ }^{-1}$. For the larger estimate of dredging removal percentage, removal has exceeded input most years since 1915. Several factors contribute to the sand deficit: dredging, sand mining, upstream flow regulation, and climate change. One apparent consequence of sand removal is lower water levels in the tidal river, with impacts that include changes in the extent of shallow-water habitat for juvenile salmonids and reduced navigation channel depths during low-flow periods.
\end{abstract}




\section{Introduction}

Purpose

The numerous functions of the LCR facilitate the need for an accurate estimate of the river's sand budget. An accurate estimate of the sand budget in the LCR aims to bring together all known sources of information relating to maintenance dredging, sand mining, and flow and transport conditions. In particular, we seek to determine whether there has been a "sand deficit" -- and excess of removal over supply -- that might in part explain the occurrence of lower water levels in Portland-Vancouver Harbor (Jay et al., 2011) and coastal erosion at the mouth of the river.

\section{Background}

Portland, OR, and Vancouver, WA, serve as a conduit for the export of agricultural products from the Willamette Valley, timber from around the Northwest, and grain, minerals, and other bulk products from the inland parts of the Northwest. In 2007, the Port of Portland (PoP) handled $\sim 14$ million tons of goods and 450,000 automobiles at its marine terminals (PoP, 2008). The PoP directly supports 14,000 jobs in the region and indirectly supports 16,000 other jobs (Martin, 2007). Trade through the PoP has a significant impact on the regional and national economy.

The U.S. Army Corps of Engineers (USACOE) and the PoP maintain a 103.5-mile-long, 43foot-deep shipping channel from the mouth of the Columbia River (MCR) to the Willamette River. The Willamette River is maintained to a control depth of 40 feet from the Columbia River up to the Broadway Bridge in Portland (PoP, 2009). The Columbia River channel consists of two components: a) the LCR navigation channel from river mile 3 (RM-3) to Portland and Vancouver and $b$ ) the MCR channel from the ocean to RM-3 (which is maintained to a deeper depth than the LCR channel).

The LCR also provides many ecosystem functions, including serving as habitat for juvenile salmon. The extent and connectivity of shallow-water habitat impacts the capacity of the LCR ecosystem to support juvenile salmon populations. The salmon need access to off-channel, shallow-water habitat in order to forage for food and avoid potential in-stream predators (Bottom, 2011). Falling water levels (Jay et al., 2011) reduce the flooding and availability of shallow- 
water habitat. In the future, reduced sediment supply may actually cause erosion of valuable habitat. Thus, long-term changes in the balance of sand input and removal have multiple effects.

\section{Methods}

Here we describe the estimation of LCR sand input and output terms.

\section{Rating Curves}

We seek to estimate changes in the LCR sand balance on a century time scale. Not surprisingly, measurements of LCR sand input/transport are rather limited, and sand inputs must be estimated for most time periods. One simple method of quantifying the magnitude of sediment transport in a river is to relate the sediment discharge to the flow rate (a "rating curve"). Flow rate is a commonly measured fluvial property. The development of rating curves serves to relate suspended sediment discharge to river-flow rate. In terms of sediment supply to the LCR, the dominant sediment contributions come from the mainstem of the Columbia River upstream of Vancouver, the Willamette River, and the highly disturbed Cowlitz River. There are no data available to allow assessments of historical (pre-dam) sediment loads for other tributaries of the Lower Columbia River, so these sources were regarded as negligible, an assumption that appears reasonable.

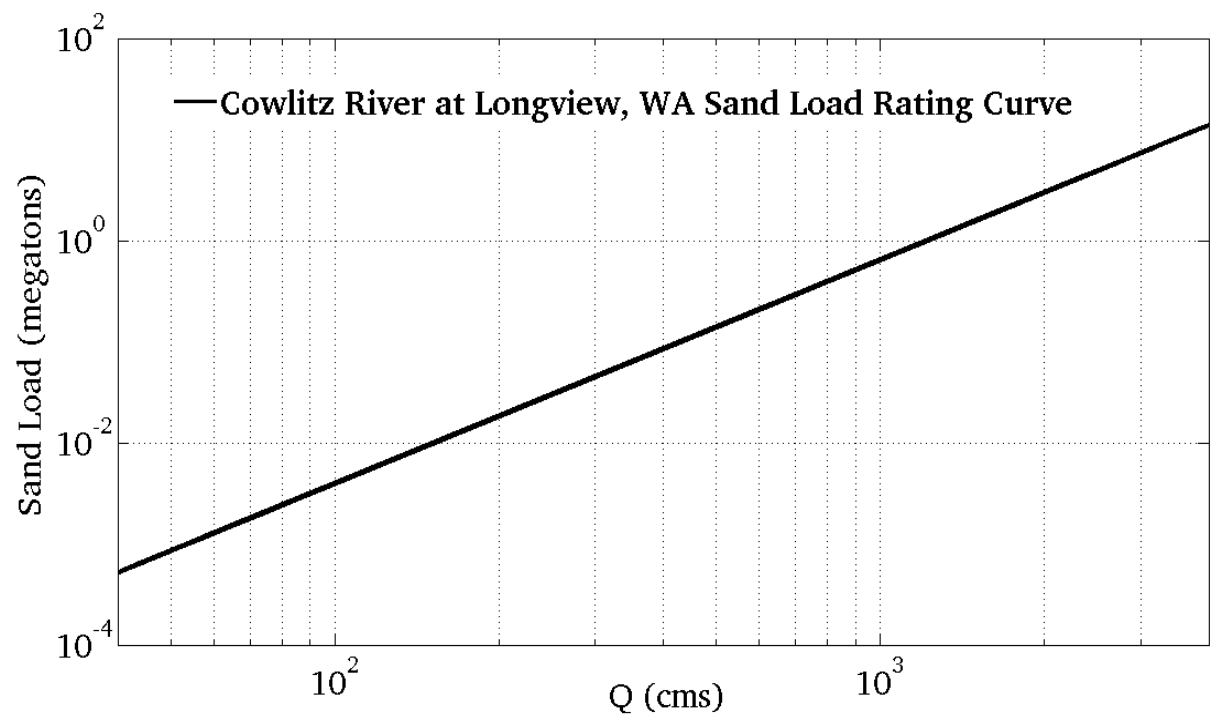

Figure 1: Rating Curve for the Cowlitz River at Longview, WA. 
Figure 1 shows the rating curve for the Cowlitz River at Longview, WA. Two other rating curves were utilized in the analysis, one for the Willamette River at Portland and one for the Columbia River at Vancouver, from Naik and Jay (2010). The Cowlitz River rating curve was developed from USGS-observed sediment load levels at Castle Rock, WA, and was adjusted downward (from the eruption of Mt. St. Helens) using more recent observed suspended-sediment load levels on the Toutle River at Silver Lake, WA.

The USGS has collected flow data at or near The Dalles, OR, since June 1878 (http://waterdata.usgs.gov/usa/nwis/uv?14105700). Flows from the Klickitat, White Salmon and Hood rivers and Mosier Creek were routed into the flow from The Dalles in order to estimate historical flows at Vancouver. Flows were hindcast for the Willamette River to 1878 (Naik and Jay, 2010). The USGS maintains flow data for the Cowlitz River at Castle Rock. The flow was scaled up from Castle Rock to Longview, in proportion to the drainage areas of the two reaches of the river. The sand-load rating curves were applied to each river to produce suspended sand loads.

Sediment-transport data were initially collected by the USGS for the Cowlitz River following the enormous sediment loads that came down the river following the eruption of Mt. St. Helens in 1980 (http://co.water.usgs.gov/sediment/seddatabase.cfm). In order to correct for the eruption, sediment-transport data from the Toutle River at Silver Lake were used to estimate the drawdown of sediment discharge in the Cowlitz River following the eruption. Suspended sedimentdischarge data exists for the Cowlitz from 1980 to 1984 (a period when loads were greatly increased due to the eruption), whereas data were collected in the Toutle River at Silver Lake from 1981-84 and 1991-95. Rating curves were developed for the Toutle River for both periods of data collection, and the relationship between the two Toutle rating curves was used to adjust the Cowlitz rating curve downward (to the same degree that Toutle River loads were reduced) from the observed 1980-84 sediment transport. This correction of the Cowlitz River sediment loads for the effects of the Mt. St. Helens eruption is plausible, but data are lacking to determine whether it is correct. However, results below suggest that Cowlitz River loads were small, except during and after the eruption, so errors in these estimates have little impact on the conclusions below.

The Cowlitz River sand load was determined for the period following the eruption (1980-1991) using the observed sand-load data in place of the adjusted rating-curve model output because the 
actual load far exceeds the rating-curve prediction, which was designed to predict the pre-St. Helens suspended sand transport. The observed data for the Cowlitz River, however, ended in 1984. The load output of the river approximately halved every year following the eruption. The suspended sand-load data from 1984 and on, therefore, was halved until halving produced a yearly load that was less than the predicted sand load from the model, at which point the model was assumed to accurately predict the Cowlitz River yearly sand load. Although there may be a relationship between the rate at which the deposited sediment is removed from the system and flow rates of the river (inordinately high flow rates scour the banks of the river and remove sediment), most of the sediment along the banks of the river has since likely been stabilized by vegetative growth.

The Cowlitz and Toutle river sediment-transport data indicate that the suspended sediment load consisted of $\sim 50$ percent sands and 50 percent fines, but there was no evident relationship between flow and percent fines for either system in any time period. Half of the total suspended load, therefore, was assumed to be composed of sand for all flow regimes in the Cowlitz River. As the Cowlitz River flows with relatively little interaction with low lying, silt-entrained deposits such as those in the Willamette Valley, it makes sense that a large proportion of the suspended sediment consists of sand. The aspect ratio of the river's cross section is also relatively large compared to those of the Columbia and Willamette rivers (and, therefore, the water velocity is relatively high), so a relatively high sand-fraction is to be expected and 50 percent sands represents a reasonable assumption.

Suspended sand transport is not the only type of sand transport -- bedload must also be considered. Bedload is about 10 percent of the total suspended sand load in the LCR on an annual average (Whetten, 1969), so the above estimated suspended sand loads were increased by 10 percent for bedload.

\section{Dredging and Sand Mining}

The U.S. Army Corps of Engineers, Portland District, (USACOE) and the Port of Portland (PoP) work together to maintain the shipping channel in the Willamette and Columbia rivers. Sand removal from the LCR began in the 1860s, when dredging of the mouth of the Willamette River by the city dredge commenced (Heineman, 1968). Heineman also outlines dredging activities by the 
PoP from 1891 to 1971. Dredging records are available from the USACOE that delineate dredging activities conducted by the USACOE in the LCR from 1906 to 1999 (USACOE, 2003).

The USACOE has catalogued data regarding the magnitude of bed material dredged by USACOE dredges and by contractors (USACOE, 2007). The USACOE also publishes maintenance disposal plans that outline by reach the volumes dredged and the corresponding disposal sites for the material. Three maintenance disposal plans were used to determine the amount of material the USACOE removes from the system relative to the total amount dredged over the same period. The plans specify dredging activity from 1986-1990 (USACOE 1991) and from 1982-1986 (USACOE, 1987) and five years of activities prior to 1976 (USACOE, 1976). The publications identify the type of dredge, the volumes dredged, and disposal sites by year.

In total, 41 percent of the material dredged during all periods of record up to 1990 was disposed of at out-of-system sites. This figure does not include MCR activities, which are much larger and fall outside of the scope of the LCR channel maintenance operations. Removal of the sediment from the mouth and the estuary, however, may also pose coastal erosion and ecological issues, but they are outside the scope of the present effort.

It was initially assumed, based on the above disposal plans, that 41 percent of dredge material handled by the USACOE was permanently removed from the system, and this value was applied to all other shipping channel maintenance dredging operations by the USACOE, 1885-2010 (scenario 1). However, this assumption very likely underestimates removal in earlier periods large amounts of sand were used for shoreline development, and several artificial sand islands were created. Thus, another scenario was also considered, in which 50 percent of dredge material was permanently removed from the system from 1885 to 2005 (scenario 2).

The USACOE is not the only source of dredging -- PoP operations must also be considered. PoP (2009) indicates that 25 percent of the material that the PoP dredges is moved to a confined inwater site that removes the material from the system. The other 75 percent is moved to the Morgan Bar, a site that primarily serves as beach nourishment, so that the material remains in the system (USACOE, 1991). Thus, 25 percent of the total amount of material that the PoP dredges from the river was assumed (in scenario 1) to be permanently removed from the LCR system over the PoP dredging history since 1891 . Given that earlier dredging likely resulted in perma- 
nent removal of a larger amount of material, 50 percent permanent removal was assumed for PoP operations in scenario 2 .

Sand mining from construction and fill has, since the early 1990s, become an important factor in sand removal from the system as upland sources of sand are exhausted. Data gathered for the PoP documents the extent of sand mining that has taken place in the LCR since 1992 (PoP, 1997, 1999 and 2004). This sand mining results in 100 percent permanent removal of material from the river system.

The PoP and the USACOE jointly maintain the Portland-Vancouver Harbor. Data provided by the PoP outlines their combined activities from 1970 to 1997 . The total amount dredged by the PoP during that period was 6.5 million cubic yards; this material was used for development and represents permanent removal from the system (USACOE, 1991). As a consequence, 100 percent of the material that was dredged in the maintenance of the harbor was added to the total amount of material that was permanently removed from the system. Comprehensive dredging data for the USACOE (USACOE, 2003) took harbor maintenance into account. The harbor maintenance dredged material was subtracted from the comprehensive dredge material, therefore, and 100 percent of the harbor dredge material was assumed to have been permanently removed from the system while 41 percent of the remainder was assumed to have been removed from the system.

Emergency dredging by the USACOE in 1980-1981 following the eruption of Mt. St. Helens resulted in the removal of $\sim 100$ million cubic yards of sediment (USACOE, 2009). Absent more information defining the rate at which emergency dredging took place, 50 percent of the emergency dredged material was assumed to have been removed in 1980, with the other 50 percent having been removed in 1981.

\section{Results}

\section{Fluvial Inputs}

Sand supplied to the LCR can be hindcast based upon the daily river flow and the sand-load rating curves. Figure 2 shows the estimated annual sand loads from 1885 to 2005 for the mainstem 


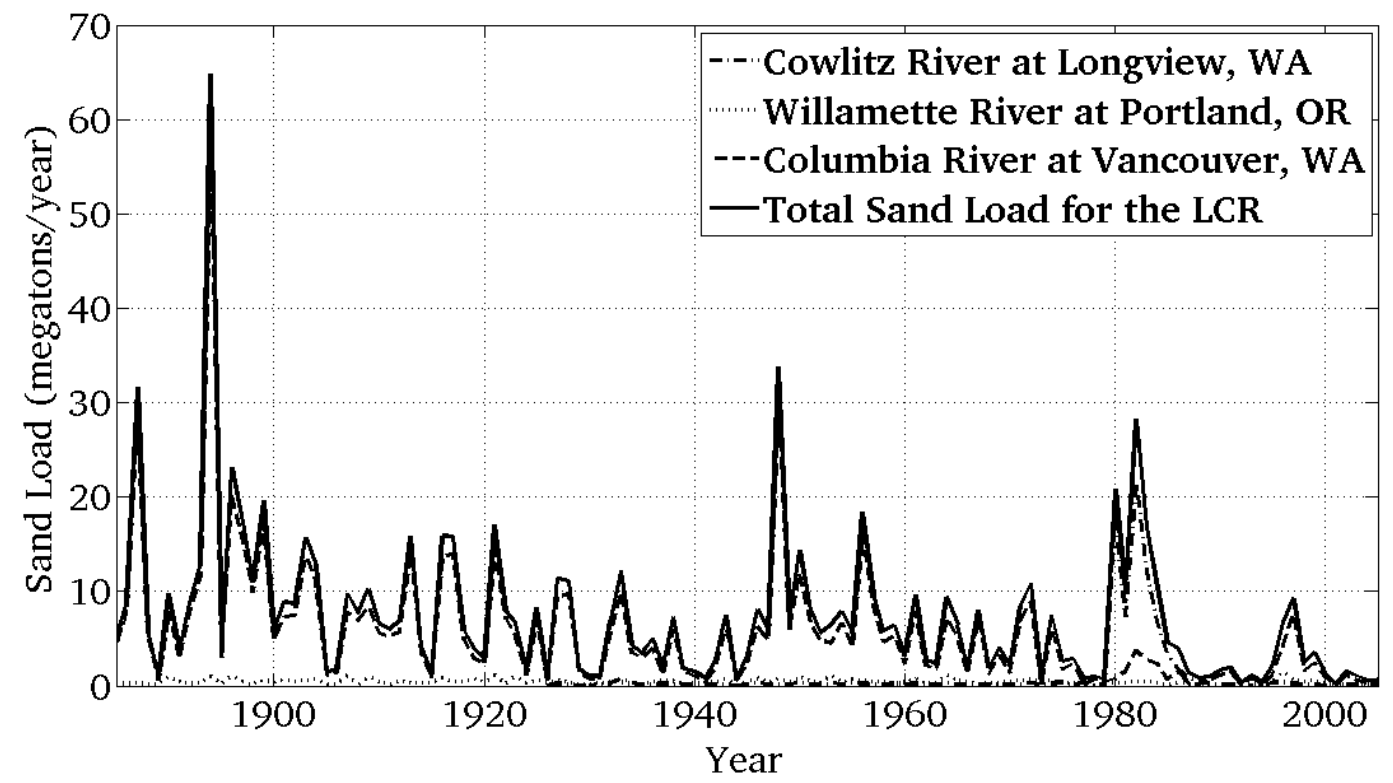

Figure 2: Sand Load for the LCR from 1885 to 2005

of the Columbia, Willamette and Cowlitz rivers. The total estimated sand load in the LCR is the summation of the sand loads for these three sources.

Figure 3 shows the long-term trends of sand removal. The peak in 1980 and 1981 represents the emergency dredging operations that took place following the eruption of Mt. St. Helens in 1980. The solid line indicates the amount of material that would be removed from the system if 50 percent of the material dredged by both the USACOE and PoP was permanently removed from the system. The dashed line indicates the amount of material that would be removed from the system if 41 percent of the material dredged by the USACOE and 25 percent of the bed material dredged by the PoP were permanently removed from the system. 


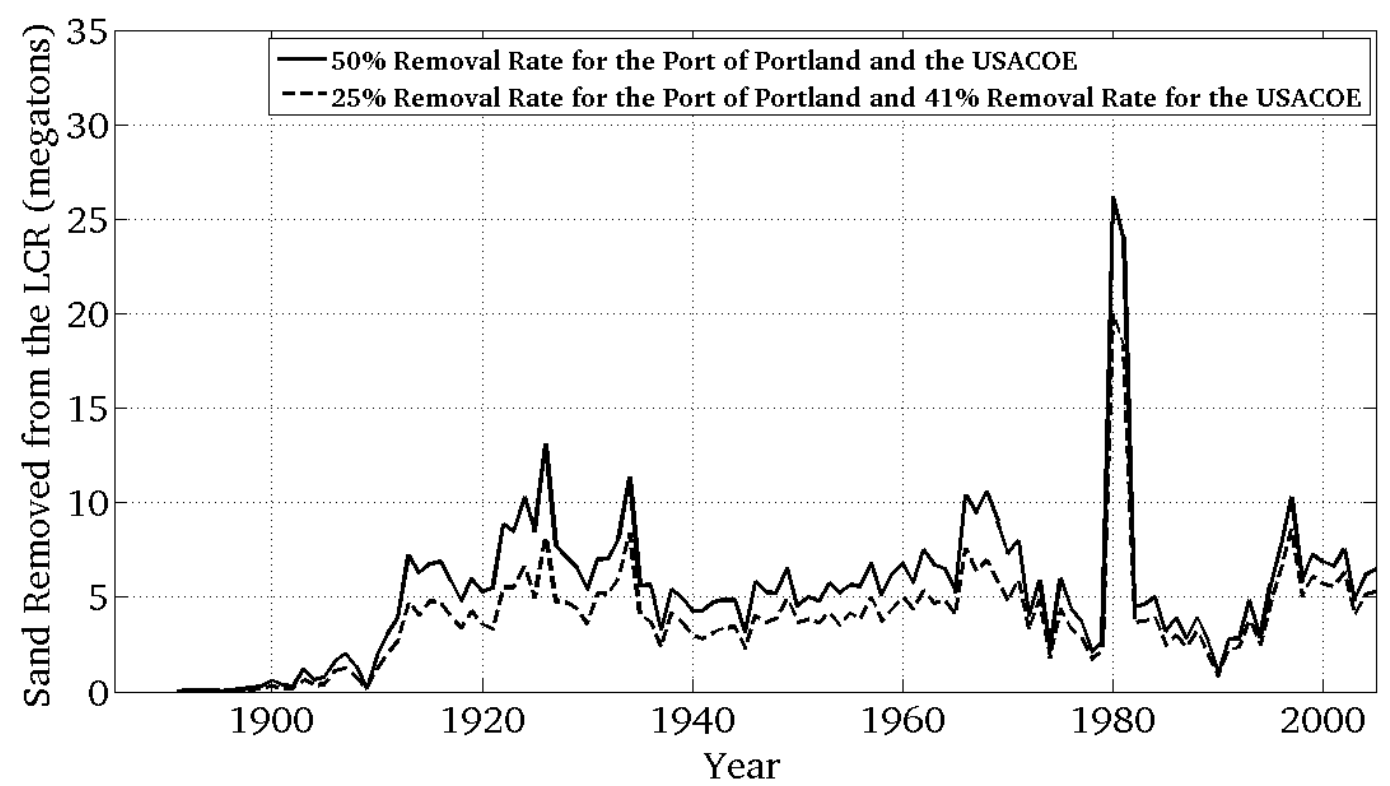

Figure 3: Sand Removed from the LCR.

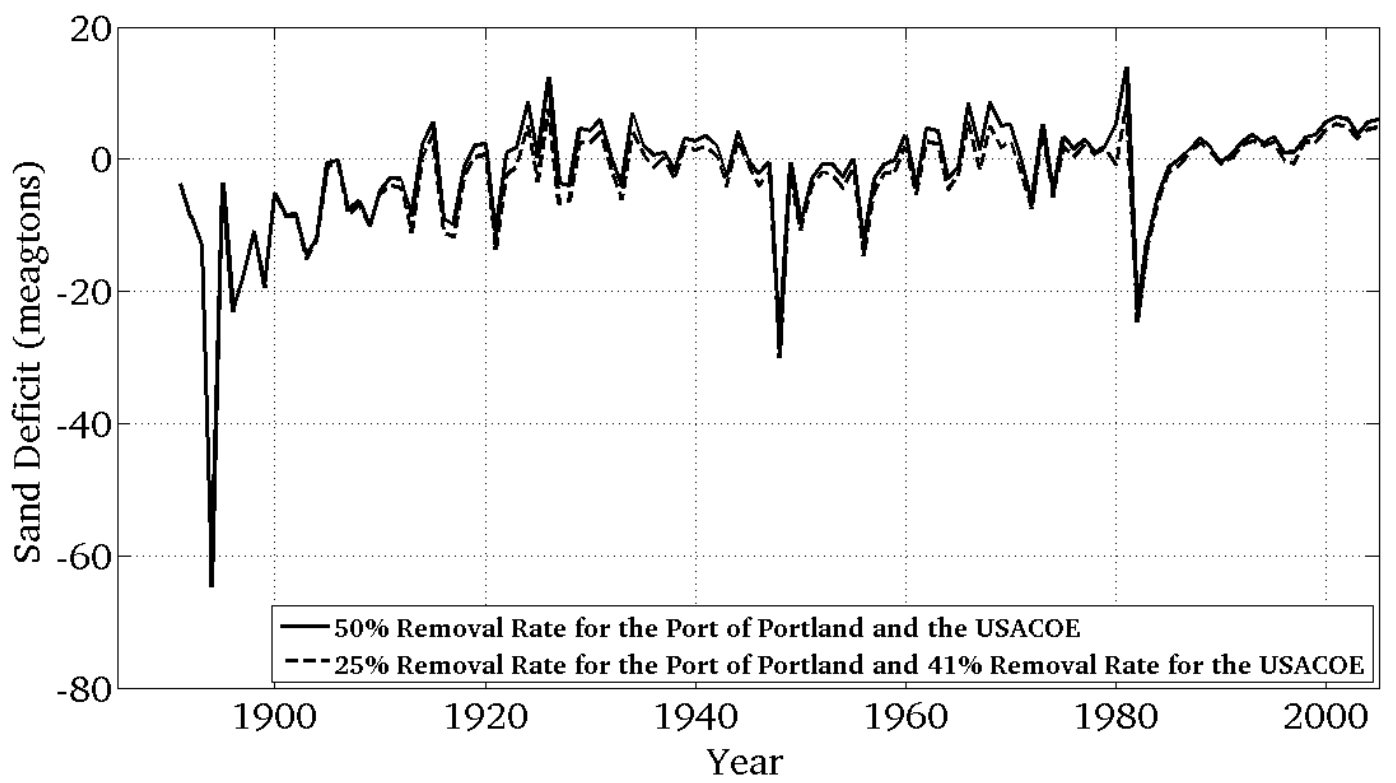

Figure 4: Sand Deficit in the LCR for two Removal Rate Scenarios

Figure 4 shows the sand deficit (the difference between supply in Figure 2 and removal, Figure 3) for the LCR 1885-2005 for both USACOE disposal scenarios (41 percent removal and 50 percent removal). Sand mining has contributed more of the amount of dredge material removed from the system in recent years, and the difference between removal scenarios has become 
smaller. Thus, variations in the assumptions surrounding the amount of material removed from the river due to dredging become less significant as sand mining increases.

The sand deficit has been positive for both scenarios 1 and 2 for most years since the end of the last cold Pacific Decadal Oscillation (PDO) in 1976, except for the period affected by the eruption of Mt. St. Helens (Figure 4). (Cold/warm PDO periods typically exhibit above/below average flows and sediment transports (Naik and Jay, 2005 and 2010)). Some years were during the warm PDO period (1925-1945), whereas sand deficits did not occur during most years of the cold PDO period dating 1946-1976. On the whole, both scenarios 1 and 2 show a net sand deficit for the period after about 1912, when extensive dredging began.

\section{Discussion and Conclusions}

\section{Reasons for the Sand Deficit in the LCR}

Significant sand deficits first occurred between 1912 and 1920, and became routine after 1922, with the exception of the 1948-1956 period of very high flows. The sand deficit in the LCR became more variable starting in the mid-1950s, even through removal showed slow, rather regular growth from 1945 to the mid-1960s. This was the result of a number of very high flow years. Dredging then increased during 1964-1975, due to channel deepening from 35 to 40 feet, then decreased from 1976-1996, except for removal of material from the Mt St Helens eruption in 1980-1981. Dredging then increased, in relation to the deepening of the channel to 43 feet. The eruption aside, the annual sediment supply has been relatively low (exceeding 10 megatons only in 1972) since 1958. Finally, the fraction of the amount of sediment handled annually that is removed from the LCR system has increased since sand mining increased ca. 1990. The net result is that there has been net removal of sand from the system most years since 1922, with the exception of 1948-1956 and 1980-1981.

Several factors contribute to the sand deficit. The two primary factors are removal by dredging, and the decrease in flows and trapping of sand behind dams due to extensive flow regulation of and irrigation withdrawal from the mainstems of both the Columbia and Snake rivers. Climate change and climate variations (such as the PDO cycles) may also play some role in decreased flows of the Columbia River. Figure 5 shows the long-term trend of the estimated suspended sand load in the Columbia River at Vancouver. The amount of sand transported through the LCR 
has decreased substantially over the past 100 years in response to upstream flow regulation and irrigation withdrawals. Sand mining did not play a major role in the system before ca. 1990, but it may play a large role in the deficit in future years.

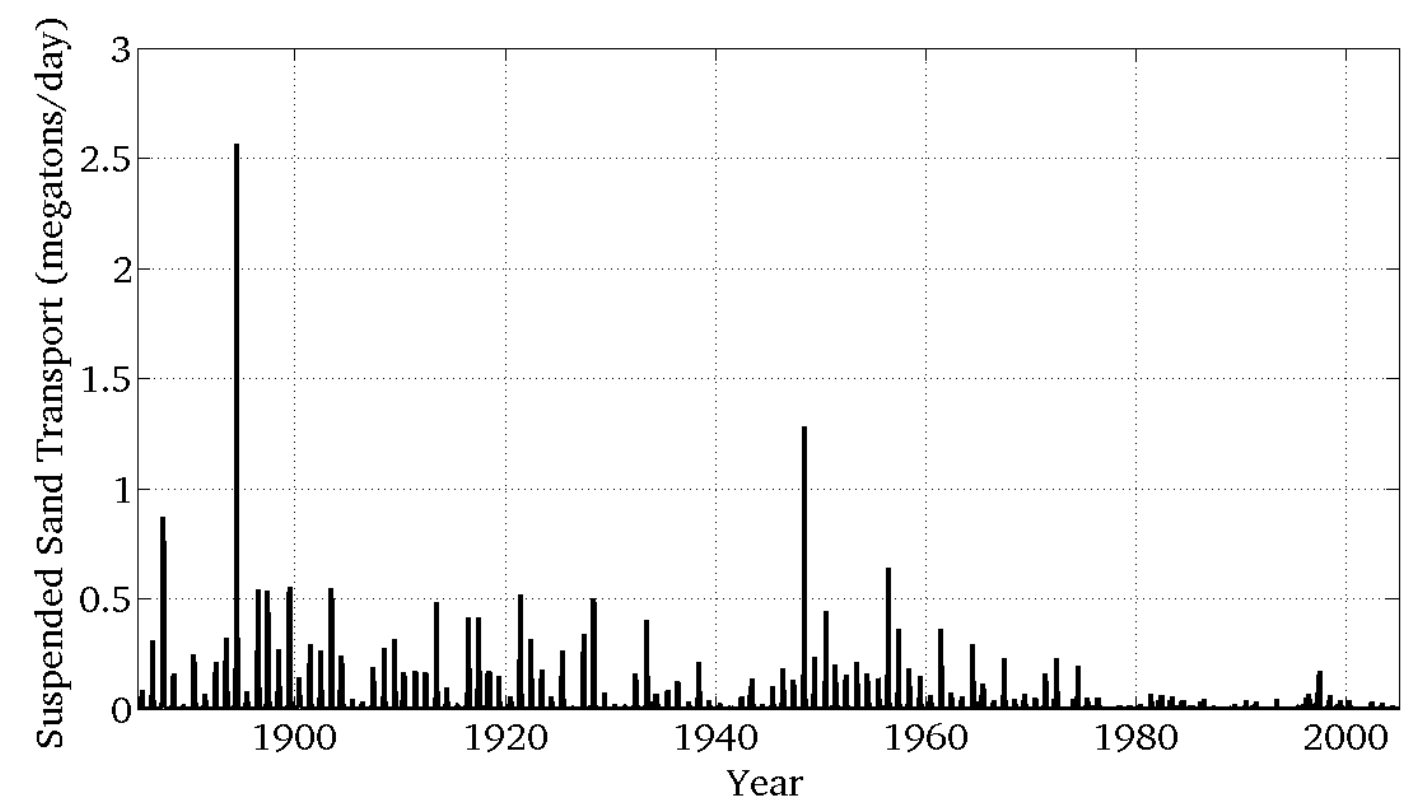

Figure 5: Long-term Trend of Suspended Sand Transport in the LCR

One way to understand the impacts of the reservoir system on the LCR sand balance is to use the rating curves discussed above to estimate the sand transport that would have taken place in the absence of flow regulation, water withdrawal and reservoir trapping. Estimates of 1878-2004 daily LCR "virgin" flows (i.e., flows unaffected by anthropogenic activities) are provided by Naik and Jay (2005). Operation of the reservoir system has flattened out the hydrograph, reducing spring freshet flows by $\sim 45$ percent in the average. Floods in excess of the natural overbank flow level $\left(\sim 20,000 \mathrm{~m}^{3} \mathrm{~s}^{-1}\right.$; defined in terms of the pre-1900 two-year return interval; Bottom et al., 2005) have been almost totally eliminated, greatly reducing sand input. Figure 6 shows the comparison between the deficit for existing conditions and the deficit for virgin-flow conditions in the LCR from 1991 to 2004. Clearly, the sand deficit would almost disappear under natural flow conditions, even with ongoing dredging and sand mining. 


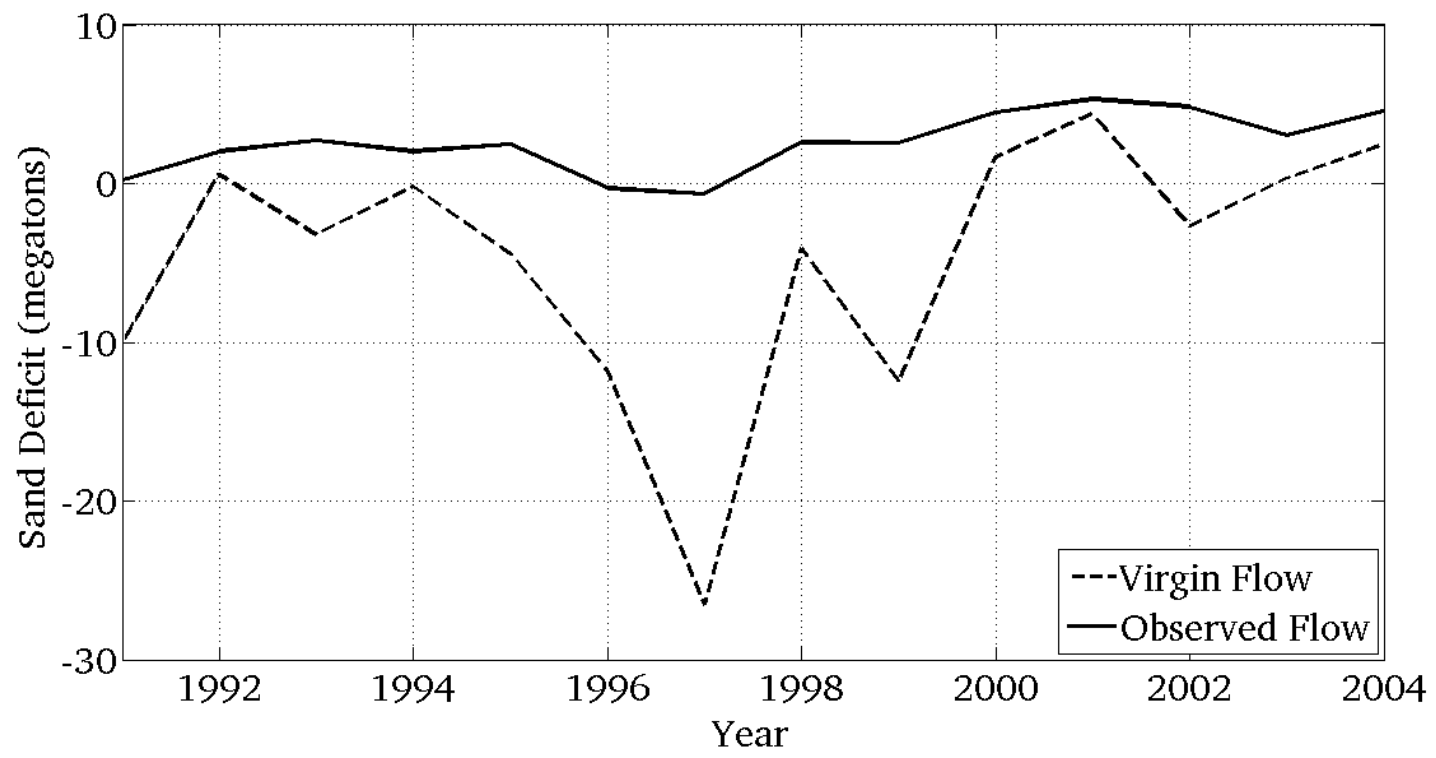

Figure 6: Comparison of Sand Deficit for Virgin and Observed Flows in the Columbia River at Vancouver, $W A$

\section{Impact of Dams on Observed Sediment Discharge}

The dams immediately upstream of the LCR do not trap sand extensively. Trapping occurs primarily in the reservoirs behind McNary Dam (completed in 1954) and the four lower Lower Snake River dams (constructed 1962-1975). The sand load predicted for virgin-flow conditions uses the existing sand-load rating curve developed from flows in the 1960s. Thus, the impacts of sediment trapping behind these dams on LCR sand transport and on the sediment rating curve for the Columbia River at Vancouver should also be considered. It is thought that the four lower Snake River dams trap about 3 megatons of sediment annually; the sand fraction of this material is not known, but is thought to be small. On the one hand, the Vancouver sand-load rating curve does not take into account the sand loads that would have been transported had the dams not been built. Thus, our rating curves may underestimate virgin-flow sediment transports. On the other hand, the Vancouver reach of the river has a very deep sand bed ( $\sim 50$ meters; Gates, 1994), due to rising sea level and deposition after the post-ice age floods. Sand transport at this location is, therefore, transport-capacity limited. Reduced supply to the lower river would occur only to the extent that the bed has been deepened (increasing cross section and reducing bed stress) by transport and removal (dredging and sand mining). Such a trend might develop over a period of decades and would alter the rating curve at Vancouver, without necessarily making transport supply limited. The existence of a trend since 1940 toward reduced water levels at Vancouver 
during high flow periods (Jay et al., 2011) suggests that bed degradation may in fact be occurring. In the absence of sediment-load data prior to the construction of the dams, we cannot directly assess pre-dam sediment transport. However, a limited amount of sediment-transport data collected by the USGS after 1970 suggest that a situation where sand supply is limited is many decades away, and that the rating curve, developed on the basis of the 1962-1969 data, is basically correct.

In summary, there is no reason to expect a strong bias in sand-transport estimates based on a rating curve derived from 1960s measurements, either before or after Snake River dam construction. The major impact of reservoir construction has been flow reduction, not alteration of the Vancouver rating curve. To the extent, however, that the upstream dams affect LCR sand supply, Figure 6 underestimates the impacts of flow regulation.

\section{Impact of Channel Geometry on Discharge and Sediment Load}

The USACOE and the PoP now maintain the shipping channel in the LCR at 43 feet deep by 600 feet wide (PoP, 2009). The process may constitute a feedback loop, however, that may conflict with the long-term goal of maintaining adequate shipping channel control depth. The bed of the LCR consists, in most places, of a thick layer of sand. Prior to the development of the navigation channel, the river was generally shallower and wider, and more variable in its cross-sectional shape due to the preponderance of shoals. These shoals acted as a frictional barrier to the flow of water. The establishment of a more regular geometry has lowered the surface elevation of the river, which requires the navigation channel to be maintained at deeper absolute elevation in order to permit the passage of the larger, deep-draft ships that now use the channel. Maintenance of the channel, especially as it consumes a greater fraction of the river's cross-sectional area, may become more difficult because of water-level drops from increasing the control depth of the shipping channel. Altered channel geometry (narrower and deeper than under natural conditions) has also increased tidal range (Jay et al., 2011). The combination of larger tidal ranges for all river-flow levels and a more hydraulically efficient channel has increased the occurrence of very low-water days during the summer-fall low-flow season. 


\section{Broader Ecosystem Impacts}

Navigation is only one of many ecosystem services provided by the LCR. An abundance of shallow-water habitat is needed in the LCR, for example, for the development and movement of subyearling and yearling salmon populations (Roegner, 2004). A significant decrease in the amount of shallow-water habitat that currently exists within the LCR and the estuary has occurred as a consequence of the sand deficit in the LCR. Diking, filling, shoreline development and flow regulation have led to a decline of $\sim 70-90$ percent of pre-European shallow-water habitat (Roegner, 2008) and a decline of $\sim 65$ percent of availability of the remaining habitat to juvenile salmonids (Kukulka and Jay, 2003).

What is the overall impact of the changes in the sand balance (supply vs. removal) on the LCR? The capacity of the river to provide the multitude of services that sand transport facilitates in the LCR has been compromised due to the decrease in spring freshet flows in the river. The significant quantity of sand that sits on the bed of the river at Vancouver can still provide a substantial supply of sand to the system (even though further sand supply has been reduced by some of the dams). The supply, however, is limited in both its quantity with regard to long-term projections of sand transport and in its capacity to be transported due to decreased peak flows in the LCR. Bank stabilization has also likely reduced sand transport. The sediment deficit in the LCR has negative impacts on shipping channel maintenance, the PoP, LCR habitat, and the stability of the surrounding littoral cells up and down the coasts of Oregon and Washington (Gelfenbaum, 1999; Blanton, 2007). If LCR shallow-water habitat is lost as the bed degrades, ecosystem effects may also be strong and negative. 


\subsection{REFERENCES}

Amin, M. "On perturbations of harmonic constants in the Thames estuary", Geophysical Journal of the Royal Astronomical Society, 73, 587-603. 1983.

Bottom, D. L., C. A. Simenstad, J. Burke, A. M. Baptista, D. A. Jay, K. K. Jones, E. Casillas, and M. H. Schiewe. "Salmon at river's end: The role of the estuary in the decline and recovery of Columbia River salmon". U.S. Dept. of Commerce, NOAA Tech. Memo., NMFSNWFSC-68. 2005.

DiLorenzo, J.L., Huang, P., Thatcher, M.L. and Najarian, T.O. "Dredging impacts of Delaware estuary tides." Proceedings of the 3rd International Conference Sponsored by the Waterway, Port, Coastal and Ocean Division, ASCE, September 8-10, 1993. Estuarine and Coastal Modeling III, Oak Brook, Illinois, pp. 86-104. 1993.

Dronkers J. J. Tidal Computations in Rivers and Coastal Waters, North-Holland Publishing Company. Amsterdam. 1964.

Flick, R. E., J. F. Murray, and L. C. Ewing. "Trends in United States tidal datum statistics and tide range." ASCE Journal of Waterway, Port, Coastal, and Ocean Engineering, 124, 155164. 2003.

Hamlet, A.F., Lettenmaier, D.P. "Effects of 20th Century Warming and Climate Variability on Flood Risk in the Western U.S." Water Resources Research 43, W06427, doi:10.1029/ 2006WR005099. 2007.

Huber, P. J. Robust statistical procedures, 2nd Ed. No. 68 in CBMS-NSF Regional Conference Series in Applied Mathematics Society of Industrial and Applied Mathematics. 1996.

Jay, D. A., 1991. "Green's law revisited: tidal long wave propagation in channels with strong topography.” Journal of Geophysical Research 96: 20,585-20,598.

Jay, D. A., 2009. "Evolution of tidal amplitudes in the eastern Pacific Ocean." Geophysical Research Letters, 36, L04603. doi:101029/2008GL036185.

Jensen, J., Mudersbach, C. H., Blasi, C. H. Hydrological changes in tidal estuaries due to natural and anthropogenic effects, Proceedings of the 6. International MEDCOAST 2003Conference, Ravenna, Italy. 2003.

Kukulka, T., and D. A. Jay. "Impacts of Columbia River discharge on salmonid habitat I. a nonstationary fluvial tide model." Journal of Geophysical Research 108, 3293 doi 10.1029/2002JC001382. 2003a.

Kukulka, T., and D. A. Jay. Impacts of Columbia River discharge on salmonid habitat II. Changes in shallow-water habitat, Journal of Geophysical Research 108, 3294 doi

10.1029/2003JC001829. 2003b. 
LeBlond, P. H., 1978. "On tidal propagation in shallow rivers." Journal of Geophysical Research $83,4717-4721$

Leffler, K. and D. A. Jay. "Enhancing tidal harmonic analysis: Robust (hybrid L1/L2) solutions." Continental Shelf Research 29, 78-88. 2009.

Mote, P., A. Petersen, S. Reeder, H. Shipman, and L. Whitely Binder. Sea Level Rise in the Coastal Waters of Washington State. University of Washington Climate Impacts Group, and Washington Department of Ecology. 2008

Naik, P.K., and D.A. Jay. "Virgin flow estimation of the Columbia River (1879-1928)." Hydrologic Processes, 10.1002/hyp.5636. 2005.

Naik, P., and D. A. Jay. "Human and climate impacts on Columbia River hydrology and salmonids." Journal of River Research Applications DOI: 10.1002/rra.1422. 2010.

Parker, B. B. "The relative importance of the various nonlinear mechanisms in a wide range of tidal interactions." In: Progress in Tidal Hydrodynamics, Ed. by B. B. Parker, John Wiley, pp. 237-268. 1991.

Woodworth, P. L., S. M. Shaw, D. L. Blackman. "Secular trends in mean tidal range around the British Isles and along the adjacent European coastline.” Geophysics Journal International 104, 593-609. 1991. 



\section{GOTREC \\ AND EDUCATION CONSORTIUM}

P.O. Box 751

Portland, OR 97207

OTREC is dedicated to stimulating and conducting collaborative multi-disciplinary research on multi-modal surface transportation issues, educating a diverse array of current practitioners and future leaders in the transportation field, and encouraging implementation of relevant research results. 